1995

\title{
Law and Legitimacy in South Africa
}

Stephen Ellmann

New York Law School, stephen.ellmann@nyls.edu

Follow this and additional works at: http://digitalcommons.nyls.edu/fac_articles_chapters

\section{Recommended Citation}

20 Law \& Soc. Inquiry 407 (1995)

This Article is brought to you for free and open access by the Faculty Scholarship at DigitalCommons@NYLS. It has been accepted for inclusion in Articles \& Chapters by an authorized administrator of DigitalCommons@NYLS. 


\section{Law and Legitimacy in South Africa}

\section{Stephen Ellmann}

This article examines whether anti-apartheid lawyering might have legitimized the South African legal system by asking what black South Africans actually thought of that system. Perhaps surprisingly, blacks, and in particular Africans, appear to have accorded the legal system a measure of legitimacy despite the oppression they often suffered at its hands. Three paradigms of African opinion are offered to help us understand the complex African response to the legal system: the conservatives, forbearing, acutely concerned with such issues as order and security, and perhaps disposed to be deferential to institutions of white authority; the speakers, fueled by faith in the truth or power of their speech, and welcoming the opportunity to be heard that courts could provide; and the activists, adamantly determined to bring down apartheid, and judging institutions and people by their contribution to that goal. For men and women thinking in these ways, anti-apartheid lawyering probably did contribute to legitimizing the legal system and that system's ideals. But this partial legitimation of the legal system is, in the end, no cause for regret; instead, it may have helped the new South Africa begin building $a$ nation governed by law.

Throughout the last years of apartheid, liberal South African lawyers declared that their country's legal system faced a crisis of legitimacy. ${ }^{1}$ In my

Stephen Ellmann is a professor of law at New York Law School. His acknowledgments appear at the end of the article on p. 479.

1. Thus John Dugard, a powerful South African critic of apartheid law for many years, wrote recently that "li]t was inevitable that blacks would lose confidence in this system of law. Consequently, for the majority of the population, the law is not legitimate." John Dugard, "Blacks and the Administration of Justice," in Dugard, ed., The Last Years of Apartheid: Civil Liberties in South Africa 95, 103 (1992) ("Dugard, Last Years"). So, too, Charles Dlamini, a prominent African legal scholar, has written: "The legitimacy crisis in South Africa has largely stemmed from the fact that black people have not felt that the law that is applicable to them is made by them and for them." Charles R. M. Dlamini, "Towards a New Legal Order for a New South Africa," 16 Legal Stud. F. 131, 136 (1992). Similarly, Nico Steytler commented that "[i]t has been said [by Albie Sachs, in 1975] that the majority of South Africans 
opinion they were right. Their comments reflected the disappointment and even despair that anti-apartheid lawyers felt at many of the decisions handed down by the South African courts and gave voice as well to the sentiments that many victims of apartheid must have felt in response to those same decisions. More broadly, however, the crisis of legitimacy the legal system faced was part of the crisis of legitimacy the entire system of apartheid faced-a crisis that now, happily, has proved to be terminal.

Despite the crisis of legitimacy they perceived, South African lawyers continued to challenge apartheid through the courts. For their part, antiapartheid movements in South Africa, adamant as they often were about rejecting participation in the institutions of apartheid, did not extend this stance to the courts. With rare exceptions, those who faced prosecution in criminal trials did so with the assistance of counsel, likely funded not by the state but rather, quite often, by foreign donors who thus supported the strategy of courtroom resistance to apartheid. Many others, who did not face prosecution, chose to initiate legal action in the hope of securing redress for some of the grievances they experienced as a result of the system of apartheid. The lawyers who represented these clients, moreover, by no means adopted courtroom strategies of total defiance; instead, their characteristic approach seems to have been to play within the rules, to press the categories of South African legal argument to their limits but still to remain within those categories. Finally, and perhaps most surprisingly, these lawyers and their clients sometimes won. ${ }^{2}$

Ironically, therefore, the same lawyers who most urgently asserted the existence of a crisis of judicial legitimacy were also engaged in litigation that invoked and sometimes demonstrated the capacity of South African law to render just results. Some worried, however, that the result of this work would be to legitimize the very system whose injustice they were challenging. ${ }^{3}$ This same concern has troubled observers of lawyering against injustice in many different countries besides South Africa, and is, of course, a focus of this symposium. ${ }^{4}$ One of its sources is the recognition that many

accord less legitimacy to their laws than perhaps any other governed group in modern society." N. C. Steytler, "Criminal Justice and the Apartheid State," in A. J. Rycroft, L. J. Boulle, M. K. Robertson, \& P. R. Spiller, eds., Race and the Law in South Africa 68, 68 (1987).

2. Stephen Ellmann, In a Time of Trouble: Law and Liberty in South Africa's State of Emergency 231-47 (1992) ("Ellmann, Time of Trouble").

3. Cf. Raymond Wacks, "Judges and Injustice," 101 S. Afr. L.J. 266 (1984).

4. Cf., e.g., Ronen Shamir, "'Landmark Cases' and the Reproduction of Legitimacy: The Case of Israel's High Court of Justice," 24 Law $\mathcal{F}^{\prime}$ Soc'y Rev. 781 (1990); Frederick E. Snyder, "State of Siege and Rule of Law in Argentina: The Politics and Rhetoric of Vindication," 15 Lawyer of the Americas 503 (1984). "Critical" scholars and others have seen similar dangers in domestic American legal contexts. For example, Austin Sarat sees legal or quasi-legal arguments used by members of the "welfare poor" as "reaffirm[ing] law's dominance even as they are used to challenge the decisions of particular legal officials - or to provide the grounds for a redress of grievances." Austin Sarat, " ". . . The Law Is All Over': Power, Resistance and the Legal Consciousness of the Welfare Poor," 2 Yale J.L. \& Hum. 343, 374 (1990). 
oppressive governments choose to enact much of their oppression through law. Certainly this was true in South Africa, where the contours of apartheid and the attendant draconian internal security powers that kept apartheid in place for over 40 years were described in abundant legislation and regulation. While apartheid also rested on illegality, up to and including torture and murder, the striking legalism of this system of injustice suggests that the whites who ruled South Africa saw the use of law as a source of legitimation of their authority. As I have argued elsewhere, white South Africans could invoke their adherence to legality as a basis for claiming membership in the community of Western nations; as a testament to their own civilization, in contrast to the barbarism they attributed to those whom they ruled; and as a gift to the subjects of apartheid, a gift from which whites could reap gratitude and respect. ${ }^{5}$ If South Africa sought to legitimize its oppression through the use of law, perhaps anti-apartheid lawyers' efforts to bend the law to better purposes were doomed to play into the hands of the architects of apartheid.

Thus the worry.' In my book on South African law, In a Time of Trouble: Law and Liberty in South Africa's State of Emergency, I argued that this worry was, as a matter of fact, not well-founded. I maintained there that litigation challenging emergency powers had contributed, modestly but still meaningfully, to protecting both individuals and political movements from even more effective repression than they would otherwise have faced. At the same time, I argued that it was unlikely that either South African whites or foreign observers had actually found much ground for asserting the legitimacy of the system of apartheid in the various emergency cases, cases that were notable both for the governmental abuses they highlighted and for the grim - though not unbroken - pattern of judicial rejection of efforts to limit those abuses. It was even more evident, as had been emphasized to me in South Africa, that black South Africans simply had not been taken in. On the contrary, black militancy had proved to be ineradicable-and we know now, in 1995, that ultimately the former victims of emergency power would sit at negotiating tables to settle the terms of the transition from apartheid to democracy and then enter the halls of government as the new leaders of a post-apartheid South Africa.

I also suggested, however, that it remained possible that emergency litigation had had a more modest legitimating effect-namely, to lend a measure of legitimacy to the legal system, as distinguished from the broader system of apartheid as a whole. It seemed to me, however, that this was no cause for regret. On the contrary, the possibility that anti-apartheid lawyering might have encouraged South Africans to see virtue in the ideals of fearless advocacy, independent judging, and the rule of law offered promise that these same ideals would be honored in a post-apartheid South Africa.

5. Ellmann, Time of Trouble 176-86. 
On this score, therefore, the possibility of legitimation was not a cost but a further benefit of anti-apartheid lawyering-but it was, also, just a possibility. ${ }^{6}$

There is no occasion now to return to the question of whether the system of apartheid could claim legitimacy among most South Africans. It could not, and so it has now come to an end-though its grim heritage, of course, will take decades to redress. ${ }^{2}$ It remains worthwhile, however, to reexamine the extent to which the efforts of anti-apartheid lawyering might have legitimized South Africa's legal system. Answering this question, in fact, is important for an understanding both of the workings of the old regime and of the process of shaping a more just successor-not only in South Africa but in other countries too.

It is appropriate to begin this inquiry by specifying its scope. Though the concept of the "legal system" is potentially a very broad one, and though much of the empirical data on which I will rely is phrased in precisely such broad language, my principal concern will be with the legitimacy of the state institution in which anti-apartheid lawyers most prominently worked - the courts. But this focus on the courts cannot be absolute, for South Africans' views of other aspects of their country's legal institutions rightly affect their assessment of their courts. We will not be able to consider South Africans' views of their courts without having in mind, to some extent, their views of apartheid's laws, of the police, and of the legal profession as well.

In asking whether the legal system retained a measure of legitimacy, and why it might have done so, I employ a concept-legitimacy-whose

6. Id. at 257-68. These arguments point to the value of the efforts anti-apartheid lawyers had made to challenge emergency powers in the South African courts. The possibility remains, however, that some other course of conduct by lawyers would have been even more effective. Perhaps the most plausible alternative would have been a Gandhian refusal to offer any defense other than an appeal to pure moral principle. In my book I suggest that in South Africa the potential reluctance of the legal community and of the victims of apartheid to engage in such tactics, as well as the possibly hostile response of the white population to them, would have made the success of a Gandhian approach dubious. These considerations helped confirm the general correctness, in the circumstances, of the continued participation in the South African legal system by lawyers and judges opposed to apartheid. Id. at 268-72. It is my understanding now, however, that certain liberal judges and lawyers did consider, or even threaten, organized acts of nonparticipation during the apartheid years.

7. In 1986, Lawrence Schlemmer wrote flatly: "Most blacks completely reject apartheid." "The Sanctions Surveys: In Search of Ordinary Black Opinion," 4 (2) Indicator SA 9,9 (1986). Indeed, the demise of apartheid may be less the immediate result of a failure of legitimacy than of the breakdown of the strategies of manipulation by which whites had maintained power despite "never [having] possessed power in the eyes of [their] subordinates." See Heribert Adam, "Engineering Compliance: The Management of Dissent in South Africa," in John Hund, ed., Law and Justice in South Africa 173, 189 (1988) ("Adam, 'Compliance' "). See generally David O. Friedrichs, "Law in South Africa and the Legitimacy Crisis," 14 (2) Int'lJ. Comp. \& App. Crim. Just. 1 (1990). 
meaningfulness has been cogently challenged by Alan Hyde. ${ }^{8}$ Hyde insists that legitimacy-defined as "the effective belief in [the] binding or obligatory quality" of a social order ${ }^{9}$ - simply cannot be shown to have any real impact on actual compliance with or resistance to the demands issuing from. that social order. ${ }^{10}$ More recent scholarship may have succeeded in demonstrating such actual impacts, ${ }^{11}$ but I will not offer,' nor should we expect, evidence that such legitimacy as the South African legal system enjoyed translated into obedience to the laws of apartheid. Such obedience would have been evidence of legitimation of the entire social order, and that is precisely what did not exist in South Africa as apartheid faded. Instead, disobedience to the laws-from political violence to rent boycotts to extremely high rates of ordinary crime-was widespread in the last days of the old regime.

But I do not mean to disavow the connection between legitimating beliefs and law-abiding behavior. It is possible that law-breaking would have been even more widespread in the absence of the measure of legitimacy I will argue existed. ${ }^{12}$ It is also possible that South Africans, ready as they were to violate many laws, were more reluctant to violate court orders, because those legal commands issued from an institution-the legal systemthat retained a degree of legitimacy. I have not searched for evidence to test this proposition, but it may exist. One South African advocate told me, for example, that he had been struck by union litigants' tendency to obey adverse court orders and appeal them, rather than simply to disobey them. Finally, and perhaps most important, it is possible that the views South Africans had of the old order's legal system have played a part in the shaping of the new South Africa-that is, in the gathering process of choice by black and white South Africans of the sorts of laws and institutions with which they are prepared to comply in the future. As we will see in the final section of this article, it is quite clear that the new South African government is a decidedly legalistic construct and that its legal institutions very much resemble those of the white-dominated government that it replaced. It is much less certain what role, if any, attitudes toward the old legal system played in the shaping of these institutions, but I will suggest that such attitudes did play a part.

Most of this article, however, focuses not on the link between legitimating attitudes and compliance but rather on the questions of whether

8. See Alan Hyde, "The Concept of Legitimation in the Sociology of Law," 1983 Wis. L. Rev. 379.

9. Id. at 380 .

10. Id. at $386-400$.

11. See Tom R. Tyler, Why People Obey the Law (1990) ("Tyler, Why Obey Law").

12. There is some evidence that many black South Africans, presumably the most likely to acknowledge no obligation to obey apartheid's laws, did feel a duty to comply with law. See note 147 infra. Even the tactics of anti-apartheid groups within South Africa may have been, as one observer emphasized to me, quite legalistic. 
such attitudes did exist and, if they did, what their sources were. In undertaking this inquiry, I mean to understand the concept of "legitimating attitudes" broadly, as "attitudes of support for an institution." "Support" is a broad term; I use it to encompass such attitudes as "approval," "confidence" and "admiration."13 These attitudes, of course, are not equivalent to a perceived "obligation to obey," the stance that people who acknowledge the legitimacy of an institution presumably adopt toward it. Nor are approval, confidence, and admiration even as closely linked to perceived obligations to obey as "attachment, loyalty, and allegiance"-forms of the "favorable affective orientation' " identified by Tom Tyler as one component of legitimacy. But it seems reasonable to suggest that attitudes of approval or confidence are closer to feelings of attachment and allegiance than are, say, attitudes of disapproval and disrespect. Hence I will argue that evidence of approval or confidence in the South African legal system is evidence of a measure of legitimacy being accorded to that system.

I begin, in part I, by arguing that, in fact, South Africans-and, in particular, black South Africans, the victims of apartheid-did accord the legal system under apartheid a measure of legitimacy. I have discussed this proposition with a range of South Africans; their reactions have ranged from believing this idea so obvious as to be unsurprising to seeing it as bizarrely incorrect. To demonstrate what I believe to be its accuracy, I will rely primarily on a body of data drawn from three national polls of people's confidence in various South African institutions. As this material will demonstrate, many or even most black South Africans expressed considerable confidence in the South African legal system. These polling data are not beyond all question, but I will look closely at the particular questions that can be raised about these results and argue that despite the problems these questions suggest the overall impression left by these polls is an accurate one.

The fact that black South Africans have accorded the legal system this measure of legitimacy sets the stage for the analysis in part II, which will seek to explain how black South Africans, and in particular "Africans"the most oppressed group of South African blacks-could have come to hold such views and will also seek to assess the role that anti-apartheid lawyering played in the generation of these views. It might be tempting to assume that if Africans in any measure approved of the legal system under apartheid, their doing so was a classic example of hegemony, understood as "power that 'naturalizes' a social order, an institution, or even an everyday practice so that 'how things are' seems inevitable and not the consequence of particular historical actors, classes, and events. It tends to sustain the interests of a society's dominant groups, while generally obscuring these in28.

13. This discussion of the components of legitimacy is guided by Tyler, Why Obey Law 
terests in the eyes of subordinates." 14 Pure instances of hegemony may be rare, but at least, it might be thought, the use of law, even when it is an act of resistance to domination and "expose[s] some of the terms of hegemony and promote[s] oppositional visions of society," also causes "the contradictions in ruling ideologies ... [to] be papered over and some aspects of domination transformed into unspoken 'truths.' "15

Though I do not want to deny the role of the "taken for granted" in human thinking, the explanations of African attitudes to the legal system that I offer do not rest primarily on the idea of popular acceptance of structures that are seen as inevitable, invisible, or natural. There are some respects in which Africans' attitudes seem very much governed by oppression, but in most respects the processes that I suggest Africans may have followed in evaluating the legal system can best be understood as conscious and rational responses to the situation in which they saw themselves. This is not to say that these responses necessarily are objectively correct (whether or not an assessment in those terms is even possible). Rather, these responses tend to be the result of beliefs "subject to open contestation"-ideologiesrather than, or at least more immediately than, of perceptions "operat[ing] unnoticed much of the time"-hegemony. ${ }^{16}$

No simple model can capture the range of these responses, but I suggest that three paradigms can help us to understand African thinking about the legal system. Let me emphasize at the outset that these three paradigms-of the groups I call the conservatives, the speakers, and the activists-are abstractions. Actual people may well have thought in the terms I associate with all three of these paradigms. In many or most respects, as we will see, these paradigms are not even theoretically inconsistent with each other; to the extent that such inconsistencies do exist, we know that people are capable of simultaneously holding somewhat contradictory beliefs. With these caveats, however, I believe these three paradigms clarify and link together a number of strands of thinking that may well have contributed to Africans' assessment of the South African legal system.

The first paradigm is of conservatism in African opinion, even under apartheid. Many Africans have been remarkably forbearing in their judgments of South African institutions. In part, and sadly, this forbearance may be the result of Africans' still laboring under the sense of their own inferiority that apartheid so vigorously and unjustly insisted on. In addition, how-

14. Susan F. Hirsch \& Mindie Lazanus-Black, "Introduction-Performance and Paradox: Exploring Law's Role in Hegemony and Resistance," in Mindie Lazarus-Black \& Susan F. Hirsch, eds., Contested States: Law, Hegemony and Resistance 1, 7 (1994) ("Hirsch \& LazarusBlack, 'Introduction' "); see Jean Comaroff \& John Comaroff, 1 Of Revelation and Revolution: Christianity, Colonialism, and Consciousness in South Africa 23 (1991) ("Comaroff \& Comaroff, Revelation").

15. Hirsch \& Lazarus-Black, "Introduction" at 8-9.

16. For this contrast between ideology and hegemony, see id. at 8 ; see also Comaroff \& Comaroff, Revelation 25. 
ever, Africans have their own heritage of communal order, and many today embrace social values that are in many respects far from insurrectionary. More prosaically, perhaps, but no less importantly, Africans' daily exposure to the perils of both political and nonpolitical crime may well have disposed many to look favorably even at stern measures taken by the country's offcial, although undemocratic, legal authorities. Moreover, many Africans may have seen some virtue in law as a tool-far from perfect but better than the available alternatives-for resolving some of the ordinary, civil legal problems of their lives under apartheid.

The second paradigm focuses on Africans as speakers, determined and enabled to tell their stories in court. Perhaps fueled by religion, perhaps guided by fundamental self-definitions, Africans have maintained that they had rights even when the statutes of their country disputed the claim. Perceiving themselves as rights holders, many may have also believed that if they were given a proper hearing, their rights would be honored. Even when they lacked this confidence, many may have welcomed the opportunity to be heard, and heard even with some measure of respect, which the higher South African courts did provide. Valuing the opportunity to speak in itself, and encouraged by their faith in the power of persuasion, Africans may have found reason to value the courts because speech was possible within their confines.

The third paradigm looks to African activists-that is, to those men and women who rejected apartheid sharply and impatiently and who were disposed to join in political mobilization in an effort to bring the old system down. These men and women, not so forgiving as the first group nor so full of faith as the second, still may have found ground for acknowledging some achievements of the South African legal system. Several factors may have contributed to their assessments, including the striking infrequency of convictions in many political trials, the moral examples offered by some antiapartheid lawyers themselves, and the guidance offered by some African leaders. But the result of these influences may not have been so much to legitimize the existing legal system itself as to help legitimize some of that system's highest but often unrealized ideals.

The final section of part II will revisit these three paradigms in order to assess the impact of anti-apartheid lawyering on the thinking these paradigms reflect. "Anti-apartheid lawyering" is a broad term, and intentionally so. I mean to encompass within it not only litigation challenging emergency powers, or undercutting such egregious apartheid statutes as the Group Areas Act, but also much more workaday legal efforts, comparable to much poverty legal service work in the United States, meant simply to address the range of daily problems oppressed South Africans faced. Thus I include in the concept of "anti-apartheid lawyering" not only defense work in political trials but also paralegal efforts to obtain individuals' pension payments. 
Moreover, I include in this concept not only litigation that explicitly challenged the tenets of apartheid law (to the extent such challenges were possible) but also litigation that took for granted the existing, oppressive framework of law and sought "merely" to ameliorate its application. Finally, I include such work whether the lawyers or paralegals performing it would have characterized themselves as liberals, or radicals, or even simply as lawyers-so long as they were acting with some sense of the injustice of the aspects of the system of apartheid against which they maneuvered and litigated. Thus defined, the network of anti-apartheid lawyering constituted a probably small but significant fraction of the South African legal profession, including some of the country's most senior and most respected lawyers as well as many who were less prominent; it also included what we will learn was a very substantial network of paraprofessionals, many of them also political activists, who in effect brought law to the people in many areas of South Africa.

What was the impact of this network's efforts on Africans' views of the legal system? I will argue that the role of anti-apartheid lawyering probably varied sharply depending on the concerns of the men and women affected; moreover, anti-apartheid lawyers are not a uniform group, and different portions of this loose community may well have had different impacts. Nonetheless, I will suggest that in each of the three paradigms I have sketched there was a potential role for anti-apartheid lawyering in enhancing Africans' views of the legal system. Whether as facilitators of modest improvements for conservatives, as facilitators of speech for those concerned to speak out, or as useful and often admired advocates for the most political, anti-apartheid lawyers likely have added to the measure of legitimacy Africans accorded to the legal system or to its ideals.

This observation in turn provides the predicate for the issue that part III of this article examines, namely, whether the legitimizing impact of antiapartheid lawyering was desirable. Part of the promise of anti-apartheid lawyering during the years of the old regime was that it might foster the rule of law in some future day. Today, we are in that future-although not yet far in - and so we now have the benefit of hindsight. I maintain that the heritage of the legal challenges to apartheid has played some part in the shaping of a new South African constitution, one which-in my judgment wisely-places considerable reliance on the entrenchment of constitutional rights to be protected by an independent judiciary.

\section{THE LEGITIMACY OF THE SOUTH AFRICAN LEGAL SYSTEM}

It might be thought that the demise of apartheid demonstrates conclusively that blacks, who make up over $85 \%$ of South Africa's population, 
opposed it and all its component parts. ${ }^{17}$ Black opposition to apartheid is very strong, but people are quite capable of opposing an oppressive system of government without believing that every institution shaped by their oppressors is unjust. Those Americans who fought the Revolutionary War against England were prepared to die to oppose continued British rule; only a few years later, however, one of the authors of The Federalist Papers would think it helpful to the cause of the new constitution to point quite approvingly to aspects of British constitutional experience. ${ }^{18}$ Moreover, even in a "crisis of legitimacy," there may still be many people who continue to defend the legitimacy of the imperiled institution. Again, American experience is instructive, for the Revolutionary War was not fought by a united mass of colonists. ${ }^{19}$

In South Africa, similarly, there appear to have been many black victims of apartheid who did not find its injustices as unbearably offensive as outsiders might presume they would have. In one 1983 survey, for example, $40 \%$ of the 1,516 African respondents said that they were "satisfied" or "very satisfied" with race relations in South Africa; $38 \%$ expressed such feelings about "respect from other race groups"; and 27\% expressed these positive feelings about "voting rights" - at a time when Africans had no vote whatsoever in national elections in South Africa! Even in 1988, when Africans' satisfaction with their lives had generally declined, 19\% (of a total of 1,199 respondents) still said they were satisfied or very satisfied with regard to voting rights. ${ }^{20}$ "Satisfaction" polls evidently tend to elicit very high levels of expressed satisfaction everywhere in the world, and Africans in South Africa were, overall, notably less satisfied with their lives, according to these polls, than people in most other countries. ${ }^{21}$ Nonetheless these figures suggest that even as apartheid ground to a halt there remained substantial numbers of Africans who were prepared to put up with it.22

In this part, therefore, therefore, we examine just what black South Africans actually did think about their system of justice. We will not find that claims of a crisis of legitimacy were unfounded; we will find, however, that a significant degree of black support for the system of justice persisted.

17. I use the term "Africans" to refer to South Africans of African descent; I use the term "blacks" to refer to all South Africans of African, mixed-race ("Coloured," in the South African terminology which, for the sake of clarity, I use), and Asian (Indian) descent.

18. See The Federalist No. 47, at 303-4 (James Madison) (Isaac Kramnick ed. 1987).

19. One scholar refers to the "popular formula" that "the American population was in equal parts Loyalist, patriot, and neutral," although he goes on to say that "it is to be suspected that the patriot element was larger than the others, both before and after 1776." John Richard Alden, The American Revolution 1775-1783 at 87 (1964). I am grateful to Kate McLeod of the New York Law School Library for this information.

20. Valerie Moller, "Can't Get No Satisfaction: Quality of Life in the 1980s," 7 (1) Indicator SA 43, 44 (1989).

21. Id. at 46.

22. Coloureds and Indians, for their part, were decidedly more satisfied, on most of these points, than were Africans. Id. at 44. 
Most of the data we will examine come from public opinion surveys. We can get a better feel for the range of blacks' views, however, if we begin with more anecdotal evidence.

\section{A. In Their Own Words: Black South Africans Assess the Legal System}

In a striking interview study done in 1988 , Robert Wilkins talked to a number of black South African lawyers and found that they viewed the legal system in which they worked as morally bankrupt, as in fact "a big farce." 23 One described judges as "just as representative of the system as [former State President] P. W. Botha." 24 Wilkins reports that "[n]early every participant [in his study] thought that all judges were unfair and that one could never get a fair trial."25 In the words of one lawyer, "if [a] matter is seen as 'political,' they convict."26 Most of these lawyers were nonetheless prepared to see some of the existing judges reappointed under a postapartheid government, but "'would not reappoint most of these white judges because of their attitudes' and would have to 'sort out the ones who were racists before.' Some lawyers noted that the 'sorting out' process would leave precious few of the previous judges qualified for the new positions."27 These harsh assessments undoubtedly represent one important strand of black opinion, and I suspect are typical of the views of many or most black lawyers. ${ }^{28}$ Lawyers from the Black Lawyers Association, with whom I spoke in late 1994 , similarly spoke very critically of the legal system; ${ }^{29}$ so did the Acting National Director (not herself a lawyer) of another mainly black legal group, the National Association of Democratic Lawyers. ${ }^{30}$

Moreover, such views are not confined just to an educated elite. Most black lawyers I interviewed believed that ordinary Africans were also largely, if not entirely, critical of the legal system. Each of the three black clients whom I formally interviewed also offered some criticism of the legal system, although the two more activist clients seemed much more severe in

23. Robert L. Wilkins, "The South African Legal System: Black Lawyers' Views," 7 (3) TransAfr. F. 9, 13 (1990).

24. Id. at 14 .

25. Id. at 16.

26. Id.

27. Id. at 28.

28. According to an "editors' note" accompanying Wilkins's piece, "a significant number" of these lawyers referred to South Africa not by that name but as "Azania." Id. at 30. This choice of terminology may reflect their sympathy with groups such as the Azanian People's Organization or the Pan Africanist Congress, both of which have taken decidedly more uncompromising positions toward whites than has the more popular African National Congress.

29. Interview with Pansy Tlakula \& Tom Lediga, 7 Nov. 1994.

30. Interview with Nomazizi Mtshotshosa, 7 Nov. 1994. 
their assessments. Jon Qwelane, a black South African journalist, recently discussed black communities' assessment of the legal system on the basis of research "in the library of the township streets and shebeens, in our taxis and township homes."31 He believes that "the perception in our communities is that one's race determines one's fate in court." 32 More vividly, he "suggest[s] that very few blacks, if any at all, will ever find anything 'fine and proud' about our judicial system, because blacks know only too well that the courts have treated most of them viciously." 33 Though recognizing the "notable but very few exceptional cases when the courts did mete out justice," he writes that "in our communities ... we hardly remember the exceptional judgments and instead remember the 'hanging judges', the cold and stony faces at the bench." 34

Yet unqualified condemnation of the legal system is not a unanimously held position among blacks. No less a figure than Nelson Mandela, seeking to recuse the magistrate before whom he faced trial in 1962 on the ground that the court was a "white man's court," was careful to say that his motion was directed to institutional rather than personal unfairness. An experienced lawyer, Mandela spoke in the language of the law: "I hold Your Worship in high esteem," he declared, "and I do not for one single moment doubt your sense of fairness and justice." $35 \mathrm{He}$ was convicted at that trial, and in a subsequent case he was sentenced to life imprisonment. He spent part of his prison years, however, in obtaining a graduate degree in law, and after his release in 1990 one observer, Anthony Sampson, was struck by "how much of Mandela's optimism depends on his respect for the law, and his trust in the integrity of another lawyer, President de Klerk."36 The year after his release, on the day he received the news that his wife Winnie Mandela had been sentenced to six years' imprisonment, he was asked if he had "now lost all confidence in the South African legal system? Mr. Mandela would not be drawn. 'It is premature,' he said, 'to deal with that point now .... Once an appeal has been made, it is proper to leave the matter in the hands of the court." 37

31. Jon Qwelane, "How Our Communities Perceive Our Legal System," in Michelle Norton, ed., Reshaping the Structures of Justice for a Democratic South Africa (Papers of a Conference Organized by the National Association of Democratic Lawyers, Oct. 1993, Pretoria) 1, 1 (1994) ("Qwelane, 'Communities').

32. Id. at 3.

33. Id. at 4.

34. Id. at 5-6.

35. Nelson Mandela, "Black Man in a White Court': First Court Statement, 1962," in Mandela, The Struggle Is My Life 125 (London: International Defence \& Aid Fund for Southern Africa, 1978). A South African lawyer has reminded me, however, that Mandela may have needed to disavow any personial attack on the magistrate for pragmatic legal reasons.

36. Anthony Sampson, "18 Days: A South African Journal," N.Y. Times Mag., 18 March 1990, at 38, 44.

37. Shaun Johnson, "Stoicism in the Mountains," in Johnson, Strange Days Indeed: Tales from the Old and the Nearly New South Africa 168-69 (London: Bantam Press, 1993). 
More recently, in October 1993, Tokyo Sexwale, once a victim of police torture and now a prominent figure in the ANC, spoke to a crowd outside the courtroom where the white alleged killers of prominent black leader Chris Hani were being tried. According to a reporter, Sexwale told the crowd: "This . . . was a trial from which the people were excluded. 'There is a white judge, a white prosecutor and white policemen ...' (the indignation was rising vocally) '... who I think have conducted an excellent investigation so far'. (The crowd's mood swung with a whump.)"38 Like the comments by Mandela, Sexwale's sentiments-though not the listening crowd's-suggest a measure of respect for the white-run South African legal system. ${ }^{39}$

Perhaps Lucas Kgatitsoe, a leader and spokesman for the Magopa, probably the last community officially subjected to a "forced removal" in apartheid South Africa, exemplifies better than any of the people quoted so far the complexity of black South Africans' views of the legal system. He spoke acidly about the old order: "as far as I'm concerned, I've never seen any right or just . . law made by the former government." 40 When the Magopa filed suit at one point in their long struggle, Mr. Kgatitsoe did not expect to win, because he "knew that . . . there's no justice in South Africa." 41 Yet the Magopa did win this case, on appeal to the Appellate Division, then South Africa's highest court. ${ }^{42}$

Why did the judges of the Appellate Division decide in favor of the Magopa? Mr. Kgatitsoe answered: "I think the judges in Bloemfontein [site of the Appellate Division] were bold enough to stand for the truth. . . . the judges stood for the right as independent judges." Partly they did so because "they knew that they are doing their duty." I asked if their decision was solely the result of their knowledge of the law and of their duty, or was also a matter of character; Mr. Kgatitose responded, "I think those judges were

38. Denis Beckett, "Textbook Law, Uncoloured by Pigment," The Star (Johannesburg), 14 Oct. 1993.

39. Neither Mandela's nor Sexwale's support is by any means unbounded. Mandela has commented: "Some of us felt strongly that there was a fundamental difference between law and justice, between legality and legitimacy." "Mandela Chides the Legal Profession," 3 RIGHTS: A Lawyers for Human Rights Publication, Oct. 1991, at 4, 5, quoted in S. Nadasen, "Changing Law in a Changing Society: Reflections from a Black Perspective," 110 S. Afr. L.J. 580,581 (1983). Sexwale has reportedly been criticized by a South African newspaper for what it saw as encouragement to ANC supporters not to acknowledge "the integrity of the court" in the same case he is discussing in the statement quoted in the text. "Finding Justice," Business Day, 18 Oct. 1993, reported in This Week in South Africa: News Highlights from the South African Media (South African Consulate General, New York, 12-18 Oct. 1993).

40. Interview with Lucas Kgatitsoe, 3 Nov. 1994, transcript at 4. Though Mr. Kgatitsoe was the sole or principal speaker during the taping of this interview, I met with him in the company of other members of the "Reef" committee of the Magopa people. The interview took place in his house in Soweto.

41. Id. at 5.

42. More v. Minister of Co-operation and Development, 1986 (1) SA 102 (A). It would be many more years, however, before they were able to return to their land. 
... very sincere, and faithful to their calling." I asked him whether he felt that most of the judges of the Supreme Court were fair, and he hesitated, and said he could speak only of the judges in his case. Those judges, however, in his opinion, were "very fair" and judged neither with favoritism toward the Magopa nor with bias against them. "They did what they knew that was right. Not to favor us . . . or the other party but to do what is right." And, in the end, Mr. Kgatitsoe was not surprised, because there are unbiased whites in South Africa and it is not surprising that someone should care to see justice done. ${ }^{43}$

\section{B. The Survey Research on "Confidence" in the Legal System}

Let us turn from the words of individuals, compelling and revealing as they can be, to the more opaque but potentially more systematic information available from survey research. Survey research in South Africa must face complex problems of diversity, unfamiliarity, and probably suspicion among those it seeks to study, and so its results surely require careful interpretation, all the more because the total sum of information gathered appears to be quite limited. Nonetheless, at least some polls do elicit strikingly blunt answers from black respondents, and so their results deserve attention. ${ }^{44}$ Here I focus primarily on the results of polls conducted by Markinor, a leading South African commercial polling agency, in 1981, 1990, and 1993, to assess, among many other topics, the degree of confidence that South Africans had in various institutions of their society. ${ }^{45}$ These polls indicate, first, that far greater numbers of black South Africans had, or used to have, confidence in their legal system than might have been expected. Second, these polls demonstrate that Africans in South Africa held substantially more favorable views of their legal system than they did of two related institutions, the police and Parliament. Third, it is clear from these polls that the views of black South Africans are not uniform and that different racial and ethnic groups within the black population expressed differing assessments of South Africa's legal system. Before examining the results in more detail, however, we must first consider carefully both the question asked and the manner of its asking, so as to gauge better how much "confidence" we should have in the answers.

43. Kgatitsoe interview, 3 Nov. 1994, transcript at 7-9.

44. For example, consider the large proportions of urban Afticans who told surveyors in 1985 and 1987 that they approved of "armed struggle" to bring about the end of apartheid. See text at note 95 infra. and 1990.

45. It is my understanding that Markinor did not poll on this question between 1981 


\section{The Question}

The question respondents were asked about confidence in institutions was phrased essentially as follows: "Please indicate, for EACH item listed here, how much confidence you have in them; is it a great deal, quite a lot, not very much, or none at all?"46 Then from 9 to 12 institutions were listed. The order and items on the list appear to have varied somewhat over the three runs of this poll, but in each case respondents were evidently asked about the "legal system," the police, and Parliament, as well as various others. ${ }^{47}$

This question plainly has ambiguities. First, the meaning of "confidence" is not necessarily self-evident. Conceivably, respondents expressing confidence in institutions meant that they confidently expected these institutions would behave in the unacceptable fashion that they had displayed in the past. But this is a strained reading of the word confidence, and as we will see, the relatively low ratings which black South Africans give to many institutions in which we would expect them to have little confidence indicate that this reverse reading of the question cannot have been widely shared.

Second, and more significantly, the meaning of the term "legal system" is not self-evident. One problem with the term is that it would not be unreasonable to say that both the police and Parliament are part of the "legal system." In that case, expressions of confidence in the legal system might embrace, or simply repeat, judgments about these other institutions. In fact, however, one of the most consistent features of the polling results is that black South Africans do not express the same levels of confidence in these three institutions; Africans, in particular, express greater confidence in the legal system in each of the three polls than they do in the police or in Parliament. 48

Thus it seems likely that respondents took the question concerning the "legal system" to refer to something broader than, or altogether different from, the police or Parliament. It is very likely, I believe, that respondents took the term to refer, at least in part, to the courts. Plainly the courts are a part of the legal system; they are also perhaps the most visible part of a

46. This is the text of the question as asked in 1990.

47. In 1990, the other institutions were the church, the armed forces, the education system, the press, trade unions, the civil service, major companies, the social security system, and the National Party. The lists in 1981 and 1993 appear to have been similar.

48. See text at notes 73-75 infra. These differences appear even when, as in 1990, respondents were asked about the legal system before they were asked about the police or Parliament. Apparently respondents differentiated between the legal system and these other institutions, at least to some extent, even before polltakers separated the institutions out through their questions. 
country's legal apparatus other than the police and the legislature. ${ }^{49}$ Thus I believe that the question concerning the "legal system" probably gives us an indication of respondents' views of the South African judiciary. My own concern, as I have said, is primarily with the courts; but if these polling questions capture attitudes toward the courts as seen within a penumbra of other legal institutions, then their focus is precisely mine.

One alternative possibility is that respondents took the term "the legal system" to refer not to the particular legal system South Africa then had but to the general idea of a legal system, or of law, as an institution of social control. In that case; the relatively high confidence ratings we are about to encounter for the legal system would be expressions of abstract approval for a form of social ordering rather than for any concrete South African institution. This reading is not inconceivable. ${ }^{50}$ Indeed, Markinor itself suggested that rather high African approval of education in 1981 might be approval of "education as such" and not of the educational system then in place. ${ }^{51}$ But here I think Markinor may have underestimated the importance that Africans attached even to the atrocious system of education they then were subjected to.

More broadly, there are two reasons why it seems unlikely that blacks' appraisals of the legal system disregarded the realities (as the respondents saw them) of South Africa's actual legal system. First, a number of the assessments blacks gave of South African institutions seem so bleak as to compel the conclusion that they were directed at the systems then in place. ${ }^{52}$ Given that, it would have been odd if poll respondents shifted their perspective when asked about the legal system. Second, the assessments of the legal system vary dramatically over the three polls, with confidence ratings quite substantial in 1981, even higher in 1990, and much lower in 1993.53 It hardly seems likely that respondents' views of the abstract idea of law under-

49. Another possible component of the "legal system" would be the civil service. Though the data I have on Africans' views of the civil service are not as complete as those on their views of the legal system, the police, and Parliament, the data do suggest that urban Africans differentiated at least to some extent between the "legal system" and the civil service, just as they did between the legal system and the police or Parliament. In 1981, more urban Africans expressed a great deal of confidence in the legal system (39\%) than offered this view of the civil service (26\%). Markinor 1981 at 92 (cited in note 51). In 1990, similarly, urban Africans were more likely to express a great deal or quite a lor of confidence in the legal system (63\%) than in the civil service (55\%). Markinor 1990 at 68 (cited in note 56).

50. Because the poll questionnaires were probably often administered to African respondents in African languages, it is clearly possible that one source of ambiguity in the poll results was the difficulty of translation. One black South African scholar suggested to me that a likely translation of "legal system" might have pointed respondents toward thinking of the idea of law in general.

51. See The Markinor South African Social Value Study - In Association with Gallup International 93 (March 1982) (cited as "Markinor 1981," since the polling for this study was done in August-October 1981). In this poll, 39\% of Africans expressed a great deal of confidence in the education system.

52. See text and note at note 73 infra.

53. See text and notes at notes $64-72$ infra. 
went such transformations, and so it does seem likely that what the respondents were addressing was their sense of the reality of their actual lives.

\section{The Asking of the Question}

For these reasons, I believe that the question asked did tap South Africans' views of their judicial system. It might still be objected, however, that the data are unreliable because the samples to whom the question was put were unrepresentative or because the manner of asking was seriously flawed. Though there may well be distortions in these data-for polling in South Africa is a challenging enterprise-the Markinor polls appear to me to have been carried out in generally appropriate fashion and to have elicited results that are likely to be credible.

Certainly the polls reached samples of each of South Africa's major racial groups. ${ }^{54}$ The 1981 poll included 600 whites; 600 Africans, all living in metropolitan areas; 200 Coloureds, all living in Cape Town; and 200 Asians, all in Durban. ${ }^{55}$ The 1990 poll covered 1,236 whites; 600 urban Africans, including squatters, and 500 rural Africans (100 from each of five "homelands"); 200 Coloureds; and 200 Asians. ${ }^{56}$ The 1993 polls covered 804 whites with telephones, as well as 1,000 metropolitan Africans, including squatters but not including hostel dwellers, 400 metropolitan Coloureds, and 400 metropolitan Asians. ${ }^{57}$

54. In addition, it is worth mentioning that examination of the polling data for 1990 and 1993 confirms that the black South Africans polled came from a substantial range of income and education levels. The 1981 data that I have do not make the socioeconomic range of respondents clear, but Markinor's report states: "All samples were quota samples, stratified by area and controlled within sex by: Age, Language/Ethnic group; Working status; Household income." Markinor 1981 at 5 (punctuation modified).

55. Id. at 5. Most discussion of this poll in this article will not be based on this report, however, but on the more detailed statistical materials, kindly provided to me by Mari Harris of Markinor, on attitudes toward the legal system, Parliament, and the police. I cite these materials as "Markinor 1981 Statistics."

56. See Markinor, The World Social Value Study-South Africa-Urban Written Report 5 (March 1991) (cited as "Markinor 1990," since the polling was done in October and November 1990). The 600 metropolitan Africans included squatters. Id. This report does not include the data gathered for the 500 rural Africans polled; detailed statistical breakdowns on the attitudes of urban and rural Africans, Coloured, and Asians toward the legal system, Parliament, and the police were provided to me by Mari Harris of Markinor and are cited as "Markinor 1990 Statistics."

The rural Africans polled came from the homelands of KwaZulu, Transkei, Lebowa, Gazankulu, and Bophuthatswana. Ms. Harris has informed me that because of the relatively small sample sizes ( 100 from each homeland), data on rural African opinion should be viewed "only as indications." Letter from Mari Harris, 17 Nov. 1993.

57. This information is drawn from the statistical breakdowns, sent to me by Ms. Harris, of data on attitudes toward the legal system, Parliament, and the police (cited as "Markinor 1993 Statistics") and from additional information which Ms. Harris provided to me concerning the methodology of another poll, Markinor Socio-political Trends (May 1993), in the course of which "confidence" questions were put to Africans and whites (different groups were evidently polled in different months). The statistical breakdowns provided to me with respect to whites are dated May 1993; those for Africans June 1993; and those for Coloureds and Asians 
In addition, the polls' survey methodology appears to have been reasonably designed to elicit candid and meaningful answers from the people interviewed, and in particular from black South Africans. ${ }^{58}$ Ordinarily, and particularly before the weakening of residential segregation in South Africa, the interviewer and the interviewee would have been from the same racial group (white, African, Coloured, or Asian). The poll questionnaires were translated into a number of African languages. Moreover, all African interviewers would have been fluent in the African language most widely spoken in the area being polled, and would have spoken one or more additional African languages. African interviewees would have chosen whether to be interviewed in English, Afrikaans, or an African language. ${ }^{59}$

Even with these rather careful polling procedures, it remains quite possible that some black South Africans would have refused to give candid answers. Though they would not likely have been speaking with an interviewer of a different race, they might still have feared that their answers might be used to their disadvantage by powerful whites. Thus it is conceivable that the levels of confidence that black South Africans expressed in the legal system masked their true, more critical judgments.

Conceivable, yes; likely, no. This theory is hard to square with the harsher judgments that the poll respondents did offer with respect to other institutions. It is also hard to square with the startlingly blunt answers respondents gave to certain other questions. In 1981 , for example, $47 \%$ of the African respondents apparently agreed that "[t]here may be certain circumstances where terrorism is justified."60 That statement was not overtly fo-

August 1993; though all of these are cited as "Markinor 1993 Statistics," the dates of the printouts are also given.

58. One possible defect of the polls is that the "confidence" questions, at least in 1981 and 1990, evidently were part of much larger questionnaires. One South African pollster suggested to me that respondents' attention might have flagged in the course of the polling. While this may well be true, the fact that respondents did not express the same levels of confidence in the related institutions of police, Parliament, and the legal system helps to confirm that those polled were still focusing on each question asked.

59. Personal communications from Mari Harris of Markinor, Nov. 1994, April 1995. The possibility of misunderstanding presumably was further reduced when the polltaker personally interviewed the respondent, rather than allowing the respondent to fill out the questionnaire himself or herself. In 1981, respondents of all races had the option to fill out the questionnaires themselves, presumably on their own. See Markinor 1981 at 6. In 1990, primarily for teasons of expense, a random sample of white respondents apparently was selected from a preestablished polling list, and the survey results for whites are principally based on the responses of those who chose to fill in the questionnaires they received $(1,086$ of 2,500$)$; all black respondents, however, were interviewed on a "personal, face-to-face basis." Markinor 1990 at 6-8. In 1993, whites were apparently interviewed by telephone, while Africans were interviewed in person, see Markinor Socio-political Trends 4. (I do not have specific information on the interviewing method used with Coloured and Asian respondents in 1993.)

60. Markinor 1981 at 96 . In 1985 and 1987 Mark Orkin, a decidedly anti-apartheid South African pollster, found that 40 to $45 \%$ of urban Africans approved of "armed struggle against the government's security forces" to bring about the end of apartheid. Mark Orkin, "Politics, Social Change, and Black Attitudes to Sanctions," in Otkin, ed., Sanctions against Apartheid 81, 85-86, 293 n.13 (1989) ("Orkin, 'Politics'). Though Orkin's question was 
cused on South African affairs, but on another question, $24 \%$ of Africans apparently agreed that " $[\mathrm{t}] \mathrm{he}$ entire way our society is organised must be radically changed by revolutionary action." 61 Even more startlingly, 13\% reported that they "had undertaken themselves or would be prepared to" engage in "[u]sing personal violence like fighting with other demonstrators or the police." 62 In addition, African respondents indicated that conduct such as "fighting with the police" and "political assassination" could sometimes be justifiable. ${ }^{63}$ In short, the people who answered the questions in these polls were capable of being quite frank; it seems unlikely, therefore, that they would have chosen to be specially discrete when it came time to estimate their confidence in the legal system.

\section{Black South Africans' Confidence in Their Legal System}

The words of the question and the manner of its asking give us reason to take the answers seriously. What we find can be stated simply. Blacks expressed a substantial level of confidence in the legal system in 1981 and an even greater level in 1990. Even in 1993, when levels of confidence fell dramatically, a significant fraction of the black community continued to express confidence in the legal system. Let us now look more closely at the details of these findings.

In its commentary on the 1981 poll, Markinor observed: "Overall, it is quite obvious that Blacks [Africans], Coloureds and Asians do not identify with institutions in which they largely have no part." 64 Certainly far greater percentages of Afrikaner whites than of blacks expressed a great deal of

focused on South Africa, while Markinor's question was not, the answers obtained seem comparable. The similarity is all the more significant since Orkin's question asked about "armed struggle," while Markinor's used the much less attractive term "terrorism." A report of the Human Sciences Research Council provides additional data of a similar cast. This report indicates that "on the question of whether violence was an acceptable means [of] achieving political aims, $63 \%$ of the Africans, $40 \%$ of the Indians, $37 \%$ of the coloureds and $30 \%$ of the whites reacted positively." Human Sciences Research Council, Main Committee: HSRC Investigation into Intergroup Relations, The South African Society: Realities and Future Prospects 86 (1985) ("South African Society").

61. Markinor 1981 at 97 (cited in note 51).

62. Id. at 94. For this question and for those referred to in the previous two sentences of the text, Markinor's report gives figures for "Total Blacks." It is not clear to me whether this term is meant to embrace Coloureds and Asians as well as Africans (ordinarily Markinor uses the term "Black" to refer to those whom I describe as "African"). If so, then the percentages of Africans expressing these views would have been even higher than the figures I have given in the text, since in each case the figure given for "Total Blacks" is higher than the figures for Coloureds and Asians.

63. Id. at 78. Asked to indicate whether these and other forms of conduct were justifiable by choosing from a 10-point scale, on which " 1 " meant "never justified" and " 10 " meant "always" justified, Africans overall rated "fighting with the police" at 3.7 and "political assassination" at "3.5." (The scores of whites for these two questions were 1.7 and 1.5, respectively; Coloureds and Asians fell between whites and Africans, but closer to whites.)

64. Id. at 93 . 
confidence in the armed forces, the police, and Parliament, and a considerably greater proportion of Afrikaners, compared to blacks, expressed such confidence in the legal system. ${ }^{65}$ But this poll also showed that half the African respondents had a great deal $(24 \%)$ or quite a lot $(26 \%)$ of confidence in the legal system, as did even greater percentages of the Coloured and Asian respondents. 66

Nine years later, in late 1990, Africans, Coloureds, and (somewhat more ambiguously) Asians all expressed even higher levels of confidence in the legal system, as table 1 shows. These are quite striking results. Apparently, in late 1990 , over $60 \%$ of urban Africans and perhaps over $75 \%$ of their rural counterparts felt a great deal or quite a lot of confidence in South Africa's legal system. It does not seem possible to say of these data, as Markinor wrote in summary of its findings in 1982, that "it is quite obvious that Blacks, Coloureds and Asians do not identify with institutions in which they largely have no part."67 On the contrary, black South Africans showed a level of confidence in their country's legal system quite comparable to that displayed by whites.

\section{TABLE 1}

Confidence in the Legal System, 1990 (Percentages)

\begin{tabular}{lccccc}
\hline & $\begin{array}{c}\text { Urban } \\
\text { Africans }\end{array}$ & $\begin{array}{c}\text { Rural } \\
\text { Africans }\end{array}$ & Coloureds & Asians & Whites \\
\hline A great deal & 27.4 & 32.9 & 13.1 & 31.7 & 28.2 \\
Quite a lot & 35.3 & 45.9 & 43.1 & 30.2 & 47.2 \\
Not very much & 21.3 & 12.8 & 28.7 & 21.0 & 18.0 \\
None at all & 10.7 & 3.6 & 1.6 & 7.4 & 2.9 \\
Don't know & 5.3 & 4.9 & 13.4 & 9.6 & 3.7
\end{tabular}

SOURCE: Drawn from "Markinor 1990 Statistics" at 163,171 , Table $86 / 4$ (cited in note 56).

65. Of Afrikaners, $56 \%$ expressed a great deal of confidence in the armed forces, $57 \%$ had this attitude toward the police, and $37 \%$ had this view of Parliament. Asians, who were more likely to express great confidence in these institutions than any other group of blacks, were still much less likely than Afrikaners; only $29 \%$ expressed this attitude toward the armed forces, $23 \%$ toward the police, and 18\% toward Parliament. Of Afrikaners, $39 \%$ held this opinion of the legal system; only $24 \%$ of Africans, $23 \%$ of Asians, and $11 \%$ of Coloureds shared it. Id. at 92 .

It should not be thought that all whites were enthusiastic about these institutions. English-speaking South Africans, long on the periphery of South African political power, were less confident than Afrikaners were in each of these institutions, sometimes dramatically less. Id. It is worth noting that the percentage of Africans expressing great confidence in the South African legal system in this poll was greater than the percentage of English-speaking whites who shared this sentiment (18\%).

66. Of Coloureds, $51 \%$ expressed such confidence ( $11 \%$ stating they had a great deal of confidence, and $40 \%$ that they had quite a lot). Of Asians, $59 \%$ had similar views ( $23 \%$ with great confidence and 36\% with quite a lot). "Markinor 1981 Statistics" at 46 (cited in note 55). Of whites, $81 \%$ had either a great deal or quite a lot of confidence. Id.

67. See text at note 64 supra. 
It might be argued that this remarkable peak in black South African confidence should be understood merely as a measure of the hopes inspired by State President F. W. de Klerk's release of Nelson Mandela and the promise of negotiations-and not as any indication of the legitimacy of the South African legal system. High hopes surely did play a part in these sentiments, but they do not justify ignoring these results. After all, the good feelings of this poll are only somewhat better than the feelings expressed in 1981, a far less promising time. If the data from 1981 capture the sentiments of black people discouraged by seemingly adamant repression by the government, and not yet energized by the mass mobilizations of the 1980s, they do no more than to reflect the kinds of conditions under which blacks lived throughout most of the era of apartheid. Additional data would of course help us understand these two years' results better, but these two snapshots of black opinion suggest that blacks may have asserted substantial confidence in the South African legal system during many difficult years of South African life.

Perhaps more important, the fact that sentiments toward the legal system could improve as a result of hopes for the end of apartheid demonstrates that black South African opinion was not irrevocably fixed. Strong as their opposition was to apartheid itself, black South Africans apparently were not utterly disenchanted with the institutions through which apartheid operated, and instead were prepared to revise their views of the institutions of South African society if they believed those institutions had become forces against, rather than for, the maintenance of injustice. Their confidence in the legal system grew as a result; the same poll reflects that their confidence in the police and in Parliament grew even more dramatically. ${ }^{68}$

After such high hopes, disappointment may be inevitable, and the tortuous course of political developments in South Africa after 1991 certainly gave frequent cause for dismay. The effects of this dismay appear in Markinor's 1993 survey. ${ }^{69}$ This time the percentage of urban Africans who expressed "a great deal" of confidence in the legal system was very small (6.3\%), though another $19.2 \%$ expressed "quite a lot" of confidence in it. More than half the urban African population this time expressed little or no confidence in South Africa's legal system. ${ }^{70}$ Confidence in Parliament and

68. Of urban blacks, $53.6 \%$ expressed a great deal or quite a lot of confidence in Parliament in 1990 (and $68.9 \%$ of rural blacks); only $24 \%$ had expressed these sentiments in 1981. Again, of urban blacks, $48.6 \%$ expressed such confidence in the police (and $69.2 \%$ of rural blacks); only 31\% had shared these feelings in 1981. "Markinor 1990 Statistics" at 166-67, 174-75 (cited in note 56); "Markinor 1981 Statistics" at 47 (cited in note 55).

69. Mari Harris of Markinor (personal communication, 17 Nov. 1993) informed me that the impact of dashed hopes reflected in these data showed up in other Markinor surveys as well.

70. Of urban Africans, 35\% expressed "not very much" confidence in the legal system, while another $25.7 \%$ expressed no confidence in it at all. "Markinor 1993 Statistics" at 20, Table 7/3 (June 1993) (cited in note 57). 
the police had also plummeted. Only $18.7 \%$ of urban Africans now declared a great deal or quite a lot of confidence in the police, and $18.2 \%$ in Parliament, compared with the $25.5 \%$ who held these views of the legal system. ${ }^{71}$ Asians and Coloureds also lost considerable confidence in South Africa's legal system, Parliament, and police between 1991 and 1993; whites too lost confidence in the legal system and in Parliament (see appendix 1). ${ }^{72}$ Anxiety and frustration took their toll in every segment of South African society during these years. Even at the end of this period, however, it is worth remembering that a quarter of the urban African population expressed considerable confidence in South Africa's legal system. Neither the frustrations after 1991, nor the years of the state of emergency before then, nor the thousands of largely unpunished political killings of recent years, had altogether dulled black South Africans' confidence in the nation's legal system.

\section{Africans' Greater Confidence in the Legal System than in the Police or Parliament}

In each of these Markinor polls, Africans in South Africa show greater confidence in the legal system than they do in two other central institutions of South African government, the police and Parliament. In 1981, for example, $24 \%$ of the African population expressed a "great deal" of confidence in the legal system. More Africans expressed this degree of confidence in the legal system than in the civil service $(13 \%)$, the police (11\%), the armed forces $(10 \%)$ or Parliament $(8 \%) .{ }^{73}$

71. Id. at 20, Table 7/3; 23, Table 7/6; 24, Table 7/7 (June 1993).

72. The levels of Coloured, Asian, and white confidence in the legal system in 1993 are shown in the table in appendix 1 . The changes in these groups' confidence in the police and Parliament from 1990 to 1993 can be summarized from their mean confidence levels (calculated by scoring "a great deal" of confidence as 4, "quite a lot" as 3, "not very much" as 2, and "none at all" as 1). Coloureds' mean level of confidence in the police fell from 2.66 in 1990 to 2.59 in 1993; their mean level of confidence in Parliament fell from 2.66 in 1990 to 2.32 in 1993. Asians' mean level of confidence in the police fell from 3.01 in 1990 to 2.60 in 1993; their mean level of confidence in Parliament fell from 2.78 in 1990 to 2.25 in 1993. Whites' mean level of confidence in the police rose from 3.24 in 1990 to 3.33 in 1993; their mean level of confidence in Parliament fell from 2.81 in 1990 to 2.47 in 1993. See "Markinor 1993 Statistics" at 23, Table 7/6; 24, Table 7/7 (Aug. 1993) (cited in note 57) (separate tables for Coloureds and Asians on identically paginated pages); id. at 22, Table 10/6; 23, Table 10/7 (May 1993) (whites); "Markinor 1990 Statistics" at 166, Table 86/7; 167, Table 86/8 (whites); 174, Table 86/7; 175, Table 86/8 (Coloureds and Asians) (cited in note 56). (All of these gaps exceed the combined "standard errors" provided by Markinor for the 1990 and 1993 data, with the exception of the modest fall in Coloureds' confidence in the police.)

73. Markinor 1981 at 92 (cited in note 51). Smaller percentages also expressed this level of confidence in "major companies" (22\%), the press (18\%), and trade unions (17\%). In fact, the only institutions in which higher percentages of Africans expressed a "great deal" of confidence were the church (45\%) and the education system (39\%).

The differences between Africans' views of the legal system and their views of the police and Parliament are also evident in the mean confidence levels. For the legal system, Africans' mean confidence level was 2.52; for the police, 2.04; and for Parliament, 1.91. "Markinor 
The 1990 data similarly indicate that Africans in South Africa-particularly urban Africans, always more radical than their rural counterpartswere more prepared to place their confidence in the legal system than in the police or Parliament. As we have just seen, the levels of confidence expressed even by urban Africans toward the police and Parliament at this time are startlingly high. ${ }^{74}$ High as these levels of confidence are, however, they are not as high as the level of confidence in the legal system: $62.7 \%$ of urban Africans had a great deal, or quite a lot, of confidence in the legal system at this time, while $53.6 \%$ had such confidence in Parliament and $48.6 \%$ had such confidence in the police (table 2). Among rural Africans the contrast is less stark, but table 2 reflects that $78.8 \%$ expressed these levels of confidence in the legal system, while $69.2 \%$ expressed comparable confidence in the police and $68.9 \%$ in Parliament.

TABLE 2

Urban and Rural African Confidence, 1990 (Percentages)

\begin{tabular}{lrrrrrrr}
\hline & \multicolumn{3}{c}{ Urban Africans } & & \multicolumn{3}{c}{ Rural Africans } \\
\cline { 2 - 3 } & $\begin{array}{c}\text { Legal } \\
\text { System }\end{array}$ & Police & Parliament & & $\begin{array}{c}\text { Legal } \\
\text { System }\end{array}$ & Police & Parliament \\
\hline A great deal & 27.4 & 21.4 & 20.9 & & 32.9 & 34.5 & 38.0 \\
Quite a lot & 35.3 & 27.2 & 32.7 & & 45.9 & 34.7 & 30.0 \\
Not very much & 21.3 & 26.8 & 25.5 & & 12.8 & 19.4 & 14.3 \\
None at all & 10.7 & 21.8 & 13.8 & & 3.6 & 8.7 & 6.6 \\
Don't know & 5.3 & 2.7 & 7.2 & & 4.9 & 2.7 & 10.2 \\
\hline
\end{tabular}

SOURCE: "Markinor 1990 Statistics" (cited in note 56): for urban Africans, 171, Table 86/4; 174 , Table $86 / 7 ; ; 175$, Table $86 / 8$; for rural Africans, 163 , Table $86 / 4 ; 166$, Table $86 / 7$; 167 , Table $86 / 8$.

NotE: For urban Africans, the means are 2.84 for the legal system, 2.65 for Parliament, and 2.50 for the police. The gaps between these means all exceed the combined standard errors reported with the data. For rural Africans, the means are 3.14 for the legal system, 3.12 for Parliament, and 2.98 for the police. Only the differences between the means for the legal system and for Parliament, on the one hand, and the mean for the police, on the other, exceed the survey's reported standard errors.

1981 Statistics" at 46-47 (cited in note 55). (These differences exceed the combined standard errors reported with the data.)

The differences between Africans views' of the legal system and of the police and Parliament are also apparent in the data on the percentages of African respondents who made clear that they did not have much confidence in these institutions. (These data are also significant as an indication that a great many poll respondents were prepared to speak their mind, and were apparently speaking it on the subject of the institutions they currently lived under, rather than addressing more abstract questions of, say, the desirability of a legal system or of a police force or a legislature.) In 1981, $75 \%$ of Africans said that they had either not very much confidence, or none at all, in Parliament, while $68 \%$ expressed such attitudes about the police, and $49 \%$ offered these views of the legal system. Id. at 47.

74. See note 68 supra. 
So, too, in 1993 urban Africans showed more confidence in the legal system than in either of the two other institutions. They were not very confident in any of these entities, but even in this period of disillusionment they did not equate the three. Of urban Africans, $25.5 \%$ had a great deal or quite a lot of confidence in the legal system at this point, as we have seen; only $18.7 \%$ held this degree of confidence in the police, and $18.2 \%$ in Parliament. ${ }^{75}$

In more hopeful moods and less, then, Africans distinguish the system of justice from other institutions and viewed it more favorably. This finding is significant because it tells us that Africans' assessments of the system of justice are not simply a function of their evaluations of all South African institutions. Instead, we now know not only that Africans (and other blacks) often held surprisingly favorable views of their legal system, and never held entirely unfavorable views of it, but also that those views are, at least in part, the result of Africans' evaluations of the particular features of the system of justice that distinguish it from other South African institutions. It appears that this system - and thus, it would seem, the courts in particular-enjoyed a measure of institutional prestige in African eyes greater than that retained by either Parliament or the police. It is the task of part II to explain the factors that may contribute to the measure of legitimacy the system of justice thus appears to enjoy.

\section{Divisions in Black Opinion}

Before we undertake that task, however, we must first recognize that the notion of legitimacy in the eyes of "blacks" can easily obscure the important differences that exist among blacks. In particular, we need to recognize the substantial gap that exists between the perceptions of Coloureds and Asians, on the one hand, and Africans on the other. This gap may well have become sharper during the years from 1981 to 1993, and its existence suggests that what may earn the legal system some degree of legitimacy in Africans' eyes may not be identical to what earns it a measure of legitimacy in the eyes of other blacks. As we will see, differences have developed, or persisted, between these groups' views of the legal system, and also-just as significantly-between their comparative assessments of the legal system and the police.

Africans, Coloureds, and Asians were all victims of apartheid. As apartheid began to break up and black men and women began to focus more on the choice among possible alternative futures than on the sources of

75. "Markinor 1993 Statistics" at 20, Table 7/3; 23, Table 7/6; 24, Table 7/7 (June 1993) (cited in note 57). The mean confidence levels were 2.07 for the legal system, 1.76 for the police, and 1.84 for Parliament. (The gaps between each of these exceed the corresponding standard errors reported.) 
present inequalities, however, these groups' assessments of the legal system seem to have developed differently. The views of Africans and Coloureds have diverged, and the sentiments of Asians and Africans may have become even more distinct than they were in 1981 . In 1981, as we have seen, $50 \%$ of urban Africans polled expressed a great deal, or quite a lot, of confidence in the legal system; almost the same percentage of Coloureds held such views $(51 \%)$ while a somewhat greater proportion of Asians (59\%) shared these sentiments. ${ }^{76}$ In 1990, as we have also seen, $62.7 \%$ of urban Africans held such views; this time both Coloureds (56.2\%) and Asians (61.9\%) were fairly comparable. ${ }^{77}$ In 1993, finally, $25.5 \%$ of urban Africans expressed these levels of confidence; a distinctly higher $37.2 \%$ of Coloureds and $35.1 \%$ of Asians, however, offered such views. ${ }^{78}$ Coloureds and Asians, in short, were apparently not so sharply disillusioned by the years between 1990 and 1993 as were Africans.

In addition, although Coloureds and Asians-like Africans-clearly do not view all the legal institutions of their society identically, they have not joined Africans in evaluating the legal system most favorably. Coloureds and Asians, instead, have viewed the police with considerably greater generosity than have Africans. In 1981, all three groups viewed the legal system more favorably than the police (and the police more favorably than Parliament), but for both Coloureds and Asians the gap between their assessments of the legal system and the police was very small. ${ }^{79}$ In 1990 , when $61.9 \%$ of urban Africans expressed confidence in the legal system and only $48.6 \%$ in the police, Coloureds and Asians gave the legal system less of an edge-or none at all. ${ }^{80}$ In 1993, finally, both Asians and Coloureds-un-

76. "Markinor 1981 Statistics" at 46 (cited in note 55). The mean confidence levels were 2.525 (Africans), 2.50 (Coloureds), and 2.71 (Asians). Id. (Only the gaps between the Asian mean on one hand, and the Coloured or African means on the other, exceed the corresponding standard errors.) Though the African and Coloured means are very close, it is striking that a much higher proportion of Africans (24\%) than of Coloureds (11\%) expressed "a great deal" of confidence at this point. Id.

77. "Markinor 1990 Statistics" at 163 , Table 86/4; 171, Table 86/4 (cited in note 56). The mean confidence levels for urban Africans were 2.84, for Coloureds 2.78, and for Asians 2.95. (Only the gap between Coloureds and Asians exceeds the corresponding standard errors.)

78. The mean confidence levels also reflect this gap: the levels for Africans were 2.07, for Coloureds 2.42, and for Asians 2.33. "Markinor 1993 Statistics" at 20, Table 7/3 (June 1993) (urban Africans); id. at 20, Table 7/3 (Aug. 1993) (separate tables for Coloureds and Asians on two identically numbered pages) (cited in note 57). (The gaps between each of these means exceed the reported standard errors.)

79. The mean confidence levels for Africans were 2.52 for the legal system and 2.04 for the police; for Coloureds they were 2.50 for the legal system and 2.48 for the police; and for Asians they were 2.71 for the legal system and 2.70 for the police. "Markinor 1981 Statistics" at 46-47 (cited in note 55). Unsurprisingly, only the two African assessments differ by more than the comesponding standard errors.

80. "Markinor 1990 Statistics" at 171 , Table $86 / 4 ; 174$, Table $86 / 7$ (cited in note 56). Of Coloureds, $59.4 \%$ expressed a great deal or quite a lot of confidence in the police, while $56.2 \%$ offered such views of the legal system; $65.0 \%$ of Asians had such views of the police, while $61.9 \%$ expressed these sentiments towards the legal system. 
like Africans-were more confident in the police than they were in the legal system. The levels of confidence these groups expressed in the police are quite striking- $49.3 \%$ of Asians and $50.5 \%$ of Coloureds expressed a great deal, or quite a lot, of confidence in the police, while only $18.7 \%$ of urban Africans held such views. ${ }^{81}$ The fact that these two groups, like South Africa's whites, ${ }^{82}$ expressed greater confidence in the police than in the legal system or Parliament may reflect relatively acute "law and order" anxieties in these groups, in contrast to persistent or growing anger at the police among Africans.

The divisions in black opinion demonstrated by these statistics point to a differentiation in the sources of legitimation as well. Coloureds and Asians were in many respects less acutely victimized by apartheid, particularly in its late years, than were Africans; nonetheless all these groups had strong reason to oppose the system of apartheid, and thus to find common ground with each other. As apartheid came to an end, however, black South Africans' attention inevitably turned from an attack on the old order to the shaping of the new. As Coloureds and Asians made this transition, they came to give substantial support to the National Party, formerly the

\footnotetext{
Measured by mean confidence levels, Coloureds' and Asians' preference for the police fades, but the contrast between their views and those of Africans remains. Urban Africans' mean confidence in the legal system (2.84) was considerably greater than their confidence in the police (2.50). (Rural Africans also were more confident in the legal system, but not so much (3.14 compared with 2.98).) Coloureds' mean confidence in the legal system, by contrast, was modestly greater than their confidence in the police (2.78 compared with 2.66). Meanwhile, Asians' mean confidence in the legal system was slightly lower than their confidence in the police (3.01 compared with 2.95), although this gap, unlike the others mentioned, fell within the compass of the corresponding standard errors. Id. at 163, Table 86/4; 166 , Table $86 / 7 ; 171$, Table $86 / 4 ; 174$, Table $86 / 7$.
}

81. "Markinor 1993 Statistics" at 20, Table 7/3; 23, Table 7/6 (Aug. 1993) (Coloureds and Asians) (separate tables for Coloureds and Asians on two identically numbered pages); id. at 20, Table 7/3; 23, Table 7/6 (June 1993) (Africans) (cited in note 57).

The mean confidence levels for Asians were 2.33 for the legal system and 2.60 for the police; those for Coloureds were 2.42 for the legal system and 2.59 for the police. Asians and Coloureds were least confident in Parliament, for which Asians' mean confidence level was 2.25 and Coloureds' was 2.32. For urban African means, see note 75 supra. The differences within each group in its attitudes to different institutions all exceed the corresponding standard errors, with the exception of the difference between Asians' mean confidence levels in Parliament and the legal system.

The proportion of the Coloured population that expressed a "great deal" of confidence in the police had actually risen, from $12 \%$ in 1981 and $9.3 \%$ in 1990 to $18.7 \%$ in 1993 -this at a time when South African confidence in general was faltering. "Markinor 1981 Statistics" at 47 (cited in note 55); "Markinor 1990 Statistics" at 174, Table 86/7 (cited in note 56); "Markinor 1993 Statistics" at 23, Table 7/6 (Aug. 1993) (cited in note 57).

82. Whites were more confident in all these institutions than were any of the black groups surveyed. Whites resembled Asians and Coloureds, however, and differed from Africans, in having the greatest confidence in the police. In 1993, $85.5 \%$ of whites expressed a great deal or quite a lot of confidence in the police; $52.1 \%$ expressed such confidence in the legal system; and 45.9\% expressed this measure of confidence in Parliament. "Markinor 1993 Statistics" at 19, Table 10/3; 22, Table 10/6; 23, Table 10/7 (May 1993) (cited in note 57). 
all-white champion of apartheid.83 A large majority of Africans, in contrast, gave their support to the African National Congress. According to the 1993 Markinor data, those Coloureds and Asians then supporting the National Party were among the strongest supporters of the South African legal system. ${ }^{84}$ Coloureds and Asians who supported the National Party also appeared to be considerably more likely than those who supported the African National Congress to place greater confidence in the police than in the legal system. ${ }^{85}$

Put in terms of legitimation, these findings suggest that South Africans now must assess competing visions of legitimation and that those South Africans who find the African National Congress' vision (as they perceive it) unattractive are more disposed both to find other political homes and to look forgivingly at South Africa's existing institutions. ${ }^{86}$ I do not suggest that the splits in black opinion between Africans, Coloureds, and Asians are absolute, but to the extent that these divisions exist they complicate our study of the sources of legitimation of the legal system. In the analysis that follows, I concentrate on identifying the sources of African opinion; in adopting this focus, we will be looking at the extent of legitimation among those South Africans who have been the most acutely victimized by apartheid and its institutions.

African opinion, in any event, is also diverse. We have already found that Africans do not express uniform views about their country's institu-

83. When South Africa's first nonracial national elections were held, in April 1994, a majority of Coloureds and Asians apparently voted for the National Party. Patti Waldmeir \& Michael Holman, "South African Elections: Spirit of Conciliation Sweeps Aside Letter of Vote," Fin. Times (London), 7 May 1994, at 3. See also Kenneth B. Noble, "South Africa's Indians Shift Loyalties," N.Y. Times, 22 April 1994, at A8.

84. Coloured respondents preferring the National Party (over half of the weighted total of all those polled) were more confident in the legal system than Coloureds with any other preference, in most cases by margins exceeding the applicable standard errors. Asian respondents preferring the National Party (about $42 \%$ of the weighted total of all Asians polled and the largest single grouping) were more confident in the legal system than those intending not to vote and those preferring the African National Congress (the next two largest groupings), again by amounts exceeding the applicable standard errors. "Markinor 1993 Statistics" at 20, Table 7/3 (Aug. 1993) (separate tables for Coloureds and Asians on identically paginated pages) (cited in note 57).

85. These contrasts can be seen in the mean confidence levels for the various groups. Asian supporters of the National Party have a confidence level of 2.76 for the police, a level higher than their confidence in the legal system (2.44); by contrast, the confidence of Asian supporters of the African National Congress in the police is only slightly greater than their confidence in the legal system ( 2.15 compared with 2.09 , a difference within the reported standard errors of the survey). Id. at 20, Table 7/3; 23, Table 7/6 (Aug. 1993).

For Coloured supporters of the National Party, the mean confidence level for the legal system is 2.59, lower than their level for the police (2.85). In contrast, Coloured supporters of the African National Congress have a confidence level for the legal system slightly higher than their confidence in the police ( 2.20 compared with 2.10 , a difference within the reported standard errors of the survey). Id. (identically paginated, separate tables for Coloureds).

86. I have sketched what I saw as competing visions of legitimation in the shaping of a post-apartheid South Africa in Stephen Ellmann, "Visions of Legitimation in Old and New South Africa: A Summary and Response," 16 Legal Stud. F. 193 (1992). 
tions. We will need to bear in mind, moreover, that different groups of Africans express different sets of views. Rural Africans tend to be more conservative than their urban counterparts. ${ }^{87} \mathrm{Zulu}$ (many part of the Inkatha movement) tend to be more conservative than Xhosa (many part of the African National Congress or more radical bodies), with such groups as Sotho in between these two extremes. ${ }^{88}$ The old tend to be among those who are most confident in the legal system (though the young do not prove as consistently radical as their prominence in street resistance to the system of apartheid might have suggested); in the cities, women may also be more confident than men. ${ }^{89}$ Education and income also affect Africans' opinions, and the data offer some suggestions that, despite the sharply critical views expressed by many African lawyers, in general those Africans who are relatively more privileged in terms of education and income hold somewhat more confidence in the legal system than do many of their counterparts. In many respects, however, Africans of widely varying income and education share similar views of South African institutions (see appendix 2). In determining what the sources of legitimation of South Africa's legal system among Africans might be, I will not offer a subgroup-by-subgroup analysis. It will be important, however, for us to distinguish broadly between different possible emphases in African thinking; as we will see, the legitimating factors at work may operate quite differently depending on the perspective, or perspectives, that particular Africans adopt.

87. For examples of this difference, see tables 1 and 2; Orkin, "Politics" at 93-94 (cited in note 60 ). As of 1987 , about $59 \%$ of the African population of South Africa above the age of 16 was rural, $14 \%$ small-town, and only $27 \%$ metropolitan, id. at 294 n.39. Orkin, at 96 , comments that "the vast metropolitan townships . . . set the political pace."

Attitudes of rural Africans also vary; in 1991 the mean levels of confidence in the legal system were 3.06 among rural Africans in KwaZulu, 3.08 in the Transkei, 3.38 in Lebowa, 2.76 in Gazankulu, and 3.14 in Bophuthatswana. "Markinor 1990 Statistics" at 163, Table 86/ 4 (cited in note 56). As noted earlier, however, these data are based on samples of only 100 people in each area, and so, according to Mari Harris of Markinor, should be viewed "only as indications."

88. E.g., the mean confidence level for the legal system among urban Zulu in 1990 was 3.05, among urban Xhosa 2.66, and among urban "Tswana/Sotho" 2.83. The gaps between each pair of groups exceed the poll's standard errors. Id. at 171, Table 86/4. Similar findings have been made in other polls. Donald L. Horowitz, A Democratic South Africa? Constitutional Engineering in a Divided Society 58 (1991) ("Horowitz, Democratic South Africa").

89. Among urban Africans the oldest people are always among those with more confidence in the legal system; in 1993, the youngest were the least confident, but that had not been true in earlier years. See "Markinor 1981 Statistics" at 46 (cited in note 55); "Markinor 1990 Statistics" at 171, Table 86/4 (cited in note 56); "Markinor 1993 Statistics" at 20, Table $7 / 3$ (cited in note 57). (Some of the comparisons between age groups, however, fall within the data's standard errors.)

From the same sources we can compare the confidence held by men and women. Urban women are more confident in each of the three polls, although only in 1993 does this gender gap exceed the reported standard errors. Rural women in 1990, however, were less confident than their male counterparts, and this gap exceeded the reported standard errors. 


\section{The Confirmation of Other Polls}

Before turning to an exploration of African thinking meant to explain the Markinor data, however, it is important to offer one further form of confirmation of those data-namely, the results of other polls. None of these polls has the combination of national scope and specific focus on the legal system that the Markinor polls do, but they do reach results whose flavor is similar to Markinor's. Moreover, these polls come from researchers, or institutions, occupying quite different spots on the South African political spectrum. Together these polls suggest that, despite the cogency of some anecdotal evidence to the contrary, there is in fact a sizable body of African opinion that accorded more legitimacy to the South African legal system than many observers might have assumed.

One striking study is the work of researchers associated with the Human Sciences Research Council (HSRC), a body which appears to have a quite conservative reputation in South Africa. In this 1988 interview study of adults in two African townships in the Durban area, KwaMashu and Umlazi, $40.9 \%$ of the people interviewed agreed with the statement that "[i]n this country nobody will be sentenced to prison without good reason," and $29.3 \%$ agreed that "[i]n the courts all people are treated justly."

Another significant study is the work of David Everatt of the Community Agency for Social Enquiry (CASE), a strongly anti-apartheid polling agency. This study is based on information recently gathered by CASE for the "Joint Enrichment Project" as a "national baseline survey of the attitudes and life circumstances of young people of all races in South Africa, aged between 16 and 30 years of age." 91 The study does not focus on courts; it does, however, investigate young people's attitudes toward law-breaking and toward the police, and so its findings are very relevant to an assessment of attitudes toward the legal system. African young people were for many years extremely prominent in the struggle against apartheid, and it might have been thought that if any group would express uncompromisingly hostile views toward the police, it would be these young people. In fact, however, $51 \%$ of African youth disagreed or disagreed strongly with the proposition that "the police are the enemy"; $62 \%$ agreed or strongly agreed

90. Rita Esterhuysen, "Views on Aspects of the Criminal Justice System," in J. M. Lötter, L. B. G. Ndbandaba, \& Rita Esterhuysen, Crime and Its Impact: A Study in a Black Metropolitan Area 184, 224, 225 (1990) ("KwaMashu/Umlazi Study").

91. David Everatt, "A Violent Generation?" (n.d.) ("Everatt, 'A Violent Generation?' "). Dr. Everatt writes in a forthcoming article, an excerpt of which he kindly provided to me, that " 2200 respondents of all races were interviewed for up to an hour and a quarter in a face-to-face questionnaire administered in the preferred language of the respondent." The questionnaire "went into the field in November/December 1992." The remainder of this paragraph is drawn from data printouts provided by Dr. Everatt. 
that "the police protect the community"; and $47 \%$ agreed or strongly agreed that "the police can be trusted."

Against the background of these figures, and of those gathered in the KwaMashu/Umlazi study, the Markinor results look entirely plausible..$^{92}$ No doubt the exact magnitude and intensity of Africans' confidence in the South African legal system under apartheid can still be debated. But we should now acknowledge that Africans did have a considerable measure of such confidence, and turn from investigating the existence of such attitudes to explaining their genesis.

\section{THE SOURCES OF AFRICANS' ASSESSMENTS OF THE SOUTH AFRICAN LEGAL SYSTEM}

The data reviewed in the previous part suggest that a sizable number of Africans in South Africa, sometimes more than half, retained a considerable degree of confidence in the South African legal system. Certainly there were always many Africans, and again sometimes more than half, who did not have such confidence and who, on the contrary, may have viewed the system, as did the lawyers in Wilkins's study, as a racist farce. Certainly, too, these South Africans had ample reason to deny the legitimacy of the legal system-a system in which an almost entirely white judiciary and a predominantly white legal profession applied laws made by a Parliament in which Africans had no representation at all, and applied them in an often conservative and sometimes blatantly racist fashion. ${ }^{93}$ For observers of South Africa, however, it is easy to see why blacks would deny the legitimacy of its legal system and why the gathering intensity of this denial would amount to a crisis of legitimacy; it is more difficult to understand why some of them would acknowledge its legitimacy instead. The first task of this part will be to explain this measure of acknowledgment. The second will be to

92. Dennis Davis, a legal scholar who relentlessly attacked the law of apartheid, has reported finding considerable faith in the Supreme Courts of South Africa in a pilot study he conducted among black South Africans in the Cape Town area. He comments: "While it is widely acknowledged that the legitimacy of the South African legal system is in crisis and has been in crisis for a long time, a surprising level of confidence still exists in some legal institutions such as the Supreme Court." D. M. Davis, "Remaking the South African Legal Order," 18 Soc. Just. 65, 77 (1991).

One other study of South Africans' attitudes toward their legal system is mentioned in an HSRC report. This 1985 report, South African Society, at 134 (cited in note 60), characterizes whites and Africans as "differ[ing] virtually diametrically in their evaluation of the administration of justice and related matters." The report refers to research showing that "whites had the most positive impression of South African law and Africans the most negative, with coloureds and Indians about midway between these two extremes. The same patterns emerged in respect of obeying the law and the perception of the police and the administration of justice." Unfortunately the report does not set out the underlying data.

93. John Dugard cogently sets out these and other sources of the challenge to the legitimacy of South African law in Dugard, Last Years 103-11 (cited in note 1). 
return to the starting point of this inquiry-the concern that anti-apartheid lawyering might have paradoxically contributed to enhancing the legitimacy of the legal system on which apartheid in good measure rested-and assess the role this lawyering work may have played in the processes that appear to account for Africans' feelings toward the legal system.

Let me emphasize that I do not suggest that Africans in substantial numbers accorded the South African legal system unalloyed legitimacy, nor do I propose to offer explanations meant to account for any such unqualified allegiance. The measure of legitimacy I argue black South Africans gave to the legal system is consistent with simultaneous, and deeply held, anger over the injustice of apartheid and, for that matter, over the injustices worked in the courts-although I suspect many black South Africans who had some respect for the courts also tried to avert their eyes as far as possible from the injustices of the system under which they lived. This measure of legitimacy is also consistent with disobedience to the law, for it is not strange for human beings to recognize some virtue in people or institutions that they sharply oppose ${ }^{44}$-although I believe it is quite possible that Africans' refusals to obey South African laws would have been even more widespread in the absence of this sentiment. With all these qualifications, however, we should not turn away from the startling question that the Markinor data pose: Why did so many Africans feel considerable confidence in the South African legal system?

In considering the possible sources of this measure of legitimacy, we need to keep in mind the variations in African opinion we have just encountered. To explain these survey data, moreover, we must go well beyond the boundaries of survey questions and answers. We will need to infer, and even to speculate, so as to tease out thoughts and connections that may lie behind the blunter responses that polls can pick up. I will try to capture the range of African opinion that might plausibly have contributed to the legitimacy of the legal system through a focus on three paradigms. The first is "the conservative," forbearing, acutely concerned with issues of order and security and perhaps with other day-to-day concerns of life, and perhaps disposed to be deferential to institutions of white authority. The second is "the speaker," determined to speak out, fueled by faith in the truth or power of his or her speech, and welcoming the opportunity to be heard that courts could provide. The third is "the activist," neither so patient as the first group nor so infused with faith as the second, but adamantly determined to bring down apartheid, and judging institutions and people by their contribution to that goal.

94. See Tyler, Why Obey Law at 62 (cited in note 11), observing: "It seems plausible that the strength of the influence of legitimacy on behavior will vary depending on other factors." 
These paradigms are abstractions; no actual person is likely to fit precisely into any one of the three, and it is very possible that actual people have firm intellectual commitments that I would classify as falling in separate paradigms. But it is not my purpose to prove the empirical validity of the paradigms as such. Rather, I utilize them because they appear to provide coherent ways to bring together threads of thought and sentiment that I do suggest contributed to Africans' assessment of the South African legal system. These threads of perception and judgment may seem unlikely to some readers. Nonetheless, I advance these inferences in order to explain the surprising, but apparently real, phenomenon of Africans' partial acceptance of the legitimacy of the South African legal system. Let us now look more closely at the thinking exemplified by each of these three paradigms and at the evidence that such thinking actually takes place, and, finally, at the role that anti-apartheid lawyering may have played in encouraging it.

\section{A. The Conservatives}

What I am calling a conservative paradigm is not a set of beliefs that are entirely interwoven, or even fully consistent, with each other. Nevertheless, there appear to be many Africans in South Africa who, despite their opposition to apartheid, have been notably moderate in many of their aspirations for change. So, too, there seem to have been many Africans for whom such concerns as "law and order" or putting food on the table were more salient than broad political transformation. And there may also have been, even in the 1980s, a significant number of Africans still affected by the feeling of inferiority that South African apartheid, like American segregation, fostered. Each of these sentiments may be called "conservative," and each of them could have reinforced the others-although I do not at all suggest that every African who held some conservative positions held all of the beliefs I am about to discuss.

\section{Africans' Moderate Responses to South African Institutions}

It might be thought that Africans, so long victimized by apartheid, would have come at last to reject every institution associated with it, wholly and unqualifiedly. African anger is real. As noted earlier, one researcher, Mark Orkin, found that $40 \%$ of urban Africans in 1985, and $45 \%$ two years later, approved of "[a]rmed struggle against the government's security forces" to bring about the end of apartheid.95 Moreover, this anger is sometimes directed precisely against judicial institutions. For example, not long ago a

95. Orkin, "Politics" at 85-86, 293 n.13 (cited in note 60). For other surveys producing comparable findings, see text and note at note 60 . 
leader of the Pan Africanist Congress issued a veiled threat that representatives of the Goldstone Commission-an independent commission headed by a white judge noted for his efforts to reduce the injustice of apartheid laws-would be killed if they attempted to inspect his organization's military camps. ${ }^{96}$ As real as African anger is, however, it is not the only consideration Africans took into account as they looked at South African institutions under apartheid.

In a variety of respects, rather, Africans prove to be decidedly less radical than might have been imagined. Lawrence Schlemmer, seemingly a more politically conservative researcher than Orkin, found in 1992 that an overwhelming majority of all population groups preferred "leaders who wanted to talk and negotiate [to] those who wanted to maintain pressure on and weaken opponents." 97 In this same survey, only $43 \%$ of Africans polled definitely endorsed the de Klerk government's "immediate resign[ation] in favour of an interim government." 98 Perhaps this less than unanimous support for de Klerk's resignation partially reflected many Africans' continued belief in de Klerk's sincerity in seeking to end apartheid. ${ }^{99}$ And it may also have reflected the considerable measure of approval that Africans had accorded to state presidents as far back as 1979; according to Markinor, urban African approval of the state president's leadership of the country never fell below $23 \%$ between 1979 and late 1993, and was below $30 \%$ only during the first two years of the states of emergency of the $1980 \mathrm{~s}^{100}$

This considerable forbearance shows up in Africans' assessments of particular issues as well. Donald Horowitz reports a number of surveys in which Africans expressed support for power sharing, rather than African control, in a future South Africa. ${ }^{101}$ A survey in mid-1991 found that most Africans

96. Maxwell Nemadzivhanani, the PAC's "national organiser," told a crowd: "Goldstone is welcome to enter Apla camps, but he should remember what happened to Piet Retief in Dingane's kraal." (Retief was killed.) Pamela Dube, "War Talk from PAC's 'Saddam,' "Weekly Mail \& Guardian, 17-23 Sept. 1993, at 6.

97. "Between Negotiation and Resistance: Views of Rank-and-File Party Supporters," Info. Update, Dec. 1992, 1, at 2.

98. Id. at 1-2. Only a few Africans (9\%), however, definitely opposed this idea. Id. at 2. The survey data came from "personal interviews" in October 1992 of 200 Asian, 1,100 African, 300 Coloured, and 400 white respondents. Elsa Thirion \& Mathilda Barnardt, "Methodology," Info. Update, Dec. 1992, at 55.

99. At the end of the difficult year of 1991, "still more than half [52\%] of [Africans] were convinced that de Klerk was sincere in his efforts to rid the country of racial discrimination." "Just how sincere is de Klerk in his efforts to eradicate racial discrimination?" Info. Update at 26 (Special Update Report 1991). By May 1993, however, only 6\% of metropolitan Africans felt that de Klerk was leading the country "very well," and only another $29 \%$ felt he was leading "fairly well." Markinor, Press Release: "Political Parties/Leaders," 15 July 1993, at 1,5 .

100. Markinor, Socio-political Trends 1993/11 (Nov. 1993).

101. Horowitz, Democratic South Africa 101-3 \& n.46 (cited in note 88). Horowitz also notes, however, that "Black opinion may ultimately be more equivocal than it is depicted here," id., and later reports a study of African students, whose attitudes toward a future described as "Black hegemony" are much more positive. Id. at 109-10. 
believed that a future Bill of Rights should protect "the rights of minority groups, be they racial, religious or cultural minorities"-a concept close to the heart of many whites, who see themselves as such a minority. The same survey also found that a majority of Africans felt that "the right to own property [should] be protected in a Bill of Rights"-again a position with which whites, as the dominant property-owners in South Africa, have reason to concur. ${ }^{102}$ Africans' support for these positions may reflect judgments of their own interests rather than patience with whites' concerns; still another survey, however, found substantial variations in Africans' views on strong affirmative action measures explicitly targeted, in whole or in part, to aid Africans. ${ }^{103}$ Several studies from the 1980 s also offered evidence that Africans, despite being sharply critical of the policies of current employers, still tended to support the principle of private ownership of businesses. ${ }^{104}$

For many Africans, it would seem, the desire to eradicate the injustice of apartheid by no means translated to a rejection of all the institutions that had been used and tainted by apartheid. Jeremy Seekings has observed that, "as Edmund Burke himself acknowledged (with respect to Britain's colonies at the close of the eighteenth century), the denial of freedom or the franchise does not make everyone a radical. Within the parameters of discontent there exists a wide range of ideological orientations. Everyday politics in South African townships rarely concerned the 'national question', providing space for particular forms of conservatism to maintain popular support."105

102. "On a South African Bill of Rights," Info. Update, July 1991, 18, at 18-19. This survey was based on a telephone sample of 2,138 people, including about 912 Africans. "Methodology," Info. Update, July 1991, at 30.

103. In this July 1992 survey, 2,000 people, including 1,100 Africans, were personally interviewed. Elsa Thirion \& Ria Joubert, "Methodology," Info. Update, Sept. 1992, at 54. They were presented with a series of proposed social policies and for each were asked whether they would "demand" it, "like it but not demand it," "dislike it but not resist it," or "fight and resist it." Lawrence Schlemmer, "Prospects for Socio-economic Conflict in South Africa: Majority Expectations, Minority Resistance," Info. Update, Sept. 1992, 22, at 22. Only 46\% of Africans said that they would "demand" that "[w]hites in civil service must be retrenched to make way for blacks, coloureds and Asians," and only $43 \%$ said they would demand that "[c]ompanies [be] forced to appoint more blacks until certain goals are reached." Id. at 27. On each of these questions, different strata of the African population ranged from below $10 \%$ "demanding" the policies to over $80 \%$. Id. Schlemmer concludes, at 28, that African "attitudes and expectations vary strongly from issue to issue," and characterizes African opinion as showing a "'pragmatic' variability."

104. See Lawrence Schlemmer, "Black Workers and the Alternative: Attitudes towards Socialism," 3 (4) Indicator SA 1, 3-4 (Autumn 1986). Markinor also found strong support for private ownership among urban Africans in 1990, although almost half wanted "owners and employees together [to] run the business." Markinor 1990 at 132-33 (cited in note 56).

105. Jeremy Seekings, "Visions of 'Community' in South Africa's Informal Township Courts" 7 (presented at the Joint Meeting of the Law \& Society Association and Research Committee on the Sociology of Law, International Sociological Association, Amsterdam, June 1991) ("Seekings, 'Visions' "). Heribert Adam, in the course of a wide-ranging analysis of the mechanisms by which South Africa's white rulers sought to retain power despite lacking legitimacy, suggests another phenomenon that might promote conservatism. As he puts it, "what Marx calls the 'dull compulsion of circumstances' " can blunt people's awareness of the 
Indeed, many Africans seem to have disengaged from "politics" as such - a reasonable stance for them to take, given how thoroughly they were excluded from lawful exercise of political power. According to Markinor's 1981 poll, $51 \%$ of the Africans surveyed said that they were not interested in politics at all (or didn't know how much interest they had), and $49 \%$ said that they never discussed politics. ${ }^{106}$ Many Africans, moreover, have found spiritual meaning in the Zion Christian Church, a church whose emphatic focus on hard work and sober moderation, rather than political change, made it the object of favorable attention from the leaders of apartheid. ${ }^{107}$ As one perceptive journalist has written:

Obscured by the revolutionary images, the great secret is that the majority of black South Africans are deeply conservative people. It's not that they are content to be governed by white men but that they are wary of sudden change, that they are devoutly religious, that they find solace in land and family and tradition, that they are intensely respectful of authority. The silent majority craves stability as much as opportunity, and more than it craves justice. ${ }^{108}$

Men and women so moderate are not friends of apartheid. But they may not make the leap of delegitimation that many observers assumed was inevitable, from dislike of apartheid to condemnation of all its institutions. Moreover, they may be reluctant to conclude, even after being the victims

possibility of alternatives to their existing situation. Adam, "Compliance" at 176 (cited in note 7). One such circumstance is sheer economic dependence, and Adam notes that for - Africans this dependence is embodied in the fact that as of 1983 almost one fifth of all employed Africans worked for the state. Id. at 177-78.

106. Markinor 1981 at 85 (cired in note 51). Whites were considerably more interested in politics, according to this survey, while Coloureds' views resembled those of Africans, and Asians' disinterest was even more intense. Id. Tom Rikhoto, the litigant in the important pass law case, Oos-Randse Administrasieraad v. Rikhoto, 1983 (3) SA 584 (A), is an example of an African man who both considered apartheid a bad system and considered himself unpoliti- * cal. Though acutely aware of the sufferings caused by the pass law system, Mr. Rikhoto described himself as nonpolitical at the time he brought his case; in his words, "I was nothing on that time. ... [I] did not know exactly for this politics or that exactly." Interview with Mehlolo Tom Rikhoto (Rikhotso), 1 Nov. 1994, transcript at 11. This interview took place in Mr. Rikhoto's residence in a Johannesburg suburb.

Interestingly, by 1990 Africans' interest in politics appeared to have risen considerably. See Markinor 1990 at 138 (cited in note 56). In 1990, moreover, urban Africans were more likely than any other group polled to believe that they could "do a great deal" about an unjust law; $21 \%$ of urban Africans held this view, compared with just $8 \%$ of South Africans as a whole. Id. at 154. This is a remarkable indication of Africans' optimism about the prospects for change in South Africa-optimism that proved well-founded. Yet African confidence in the legal system was higher in 1990 than in 1981 (see text at notes 64-68 supra). Thus it would seem that if political disengagement was connected to the considerable degree of confidence Africans expressed in 1981, other factors were able to sustain even greater confidence in 1990 .

107. Bill Keller, "A Surprising Silent Majority in South Africa," N.Y. Times Mag., 17 April 1994, at 34.

108. Id. at 37. 
of injustice at the hands of some officials or institutions, that all similar officials or institutions deserve contempt. These refusals to generalize may be very important to the makeup of South African opinion on the legal system.

Consider Jon Qwelane's statement, which I have heard echoed more than once, that "I am certain that none of the 19 million people whom the courts sent to prison under the Pass Laws will ever sing praises about the 'fine and proud traditions' of the judiciary."109 It would be hard to overstate the injustices of the pass law system. But did Africans view this system as the true essence of their legal system? ${ }^{110}$ One veteran white critic of South African law commented to me that his pass court clients could and did evaluate and approve of other aspects of the courts' functioning even as they disapproved of the operation of the pass laws. An African lawyer, Thandi Orleyn, commented that many Africans didn't have a great deal of trouble with the pass laws. ${ }^{111}$ She went on to say that, in Johannesburg in particular, the pass courts were in a separate building; by contrast, "when you walked to the Supreme Court for instance then you would see more people, you would see reporters, you'd see the more liberal people, who would be seen, even if they were white, as being in favor of the African oppressed person."112

It seems possible, moreover, that Africans disposed to view South African institutions with considerable tolerance would have found it easier to do so in the case of the courts because of their fairly limited contact with them. There is evidence in the United States that familiarity with the various actors in the legal system breeds discontent. ${ }^{113}$ Perhaps the same mechanism is at work in South Africa. Presumably Africans' principal contacts with South Africa's legal apparatus have been with the police rather than with the courts. Moreover, their principal contacts with the courts would have been with the lower courts, such as the pass courts and the magistrates' courts, rather than with the higher courts-the Supreme Courts-or the court of last resort, the Appellate Division of the Supreme Court. And their

109. Qwelane, "Communities" at 4 (cited in note 31 ).

110. I am grateful to Howard Venable for emphasizing this issue.

111. Interview with Thandi Orleyn, 10 Nov. 1994, transcript at 5. Ms. Orleyn is the director of the Johannesburg office of the Legal Resources Centre, a leading public interest law organization in South Africa.

112. Id. Such aspects of the courtroom scene might be very important to the overall impact of exposure to the legal process. Cf. Sally Engle Merry, "Courts as Performances: Domestic Violence Hearings in a Hawai'i Family Court," in Lazarus-Black \& Hirsch, Contested States 35, 37 (cited in note 14) (emphasizing the "ritual demarcation of space, costume, and language" in the courts).

Probably many Africans were also prepared to differentiate among police. Thus Tom Rikhoto distinguished between police officers who were just doing their job, and who "just want to live and the children ... must eat," and others who "you can see it's like not a person like you." Rikhoto interview, 1 Nov. 1994, transcript at 9.

113. See Austin Sarat, "Studying American Legal Culture: An Assessment of Survey Evidence," 11 Law \& Soc'y Rev. 427, 439 (1977). 
knowledge of these higher courts would surely have been modest, for one of the results of the oppression under which Africans have lived is that their knowledge of the details of many of the issues and institutions of South African life is often limited. ${ }^{114}$

While the pass courts were undoubtedly the focus of great resentment and the magistrates' courts may also have been widely criticized, Africans might have viewed the more distant higher courts with greater approval. This stance would have been all the easier to take if the information they did have made the higher courts appear to be, as Ms. Orleyn's comment suggests, the province of powerful-and somewhat sympathetic-whites. Thus Tom Rikhoto explained his confidence that the Appellate Division would uphold the lower court ruling in his favor in part on the ground that "Johannesburg is just a town but there ... there was not the law. And ... the Transvaal it was a territory. But all the laws it was from Bloemfontein," the site of the Appellate Division. Bloemfontein was, for Mr. Rikhoto, like the "head office for the whole South Africa."115 For Africans of this temper, the comparative virtues of the more distant courts might have substantially affected their assessments of the "legal system" as a whole, even though their day-to-day experience of the law may have been much less benign.

This perspective may help us to understand the responses of Africans to questions on their support for policies that would directly affect the legal system. In a recent survey $52 \%$ of Africans stated that people like them would "demand" that immediately "[b]lacks be appointed as magistrates and judges instead of whites."116 This answer reflects strong feelings on this issue-feelings that are entirely understandable in light of the virtually all-

114. This observation, condescending as it may sound, is not meant that way; it reflects the findings of polltakers of varying political orientations and appears to reflect a reality of public opinion throughout the underdeveloped world. See Orkin, "Politics" at 88 (cited in note 60); see also Schlemmer, 3 (4) Indicator SA at 4 (cited in note 104) (finding "very little evidence of a consistent ideological paradigm [among Aftican workers] ... as one would no doubt expect among poorly educated workers").

This reality goes a long way to explain the sometimes very high numbers of Africans who respond to public opinion polls by saying that they do not have an opinion on the matter at issue. For example, "some $40 \%$ of respondents [apparently all Africans] across the country had not heard of the issue" of economic sanctions against South Africa before being polled about it in the mid-1980s. Orkin, "Politics" at 88. Respondents' suspicion of and unfamiliarity with the process of public opinion polling can also obscure their opinions; it appears, e.g., that over $40 \%$ of rural African respondents in Orkin's study declined to answer a question concerning their political allegiance. Id. at 94 .

115. Rikhoto interview, 1 Nov. 1994, transcript at 14-16.

116. See Lawrence Schlemmer, "Conflict in the New South Africa: Class, Culture and Power," Info. Update, Dec. 1992, at 4, 5. In this survey, respondents were presented with various possible actions a new government might take and asked whether "people like you" "will demand it immediately and not be satisfied without it," "would like it but not at once," "would not like it," or "will oppose it and try to prevent it." In my description of this survey, I rely primarily not on Schlemmer's article but on the text of the survey and a detailed breakdown of the answers, apparently separately published and kindly provided to me by Ian Hirschfeld of the HSRC. I cite this material hereafter as "Conflict Survey Materials." 
white character of the South African judiciary until now. ${ }^{117}$ But it is striking that Africans were even more likely to mention housing opportunities, free schooling, and desegregated schooling as demands. ${ }^{118}$ They were also more likely to rate "blacks being appointed to good jobs instead of whites wherever possible" as a demand than to give this label to the appointment of blacks as judges and magistrates. ${ }^{119}$ Moreover, the call for blacks to be "appointed as magistrates and judges instead of whites," though not without its ambiguities, seems decidedly more modest than the proposal that blacks be "put in charge of the police and army." In response to the latter suggestion, which put black control, not just black appointments, at issue, only $35 \%$ of the African respondents said that people like them would demand it. ${ }^{120}$ Probably much of this forbearance is simply a result of Africans' pragmatic conclusions that they need other changes more urgently. Yet it seems reasonable to say, as well, that many Africans evaluated the need for changes in their legal system with a considerable degree of moderation, and that this evaluation is consistent with the inference that they saw some measure of virtue in the system as it stood.121

\section{Day-to-Day Concerns as Sources of African Legitimation: The Issue of Crime Control}

Given the considerable conservatism of African opinion, it is not strange that many Africans would be concerned with an issue so prosaic and

117. Now, in 1995, there are about 10 black judges, permanent or acting, on the Supreme Courts (whose various divisions roughly correspond to the federal judiciary in the United States), but most of these have probably only been appointed since the nonracial elections of last year. Two other black Supreme Court judges have been elevated to the new Constitutional Court. South Africa's next tier of courts is presided over by magistrates; as of 1991 there were 28 black magistrates out of a total of 1014. Desiree Hansson, "Selected Statistics on the South African Criminal Justice System," 1992 S. Afr. Crim. Just. 317, 325. The proportion of black magistrates has since increased, however, with the incorporation of the magistracies of the four putatively independent African homelands after they were formally reunited with South Africa. African traditional leaders or chiefs continue to exercise a subordinate jurisdiction within their own ethnic groups.

118. Of Africans surveyed, $70.77 \%$ rated "white schools having to accept all black children who wish to attend" a demand; $69.74 \%$ said people like them would demand "free schooling for all children"; and $63.74 \%$ described "housing opportunities for poor black people in places where they choose to live, even if close to white areas," as a demand. "Conflict Survey Materials."

119. Of Africans, $61.37 \%$ viewed such appointments to "good jobs" as a demand. Id.

120. Of Africans, $26.52 \%$ said people like them "would not like" this policy, and another $3.16 \%$ said people like them would "oppose it and try to prevent it"! Id. On the question of appointment of blacks as magistrates and judges, $12.69 \%$ said people like them would not like it and $3.55 \%$ said people like them would oppose it and try to prevent it. Id.

-121. Lawrence Schlemmer comments that on the issue of appointments to the judiciary "many blacks are not insistent on quick results." Schlemmer, Info. Update, Dec. 1992, at 6 (cited in note 116). Nonetheless he ranks this issue as the 6th highest, out of 24 , in his listing of issues with "conflict potential," because the substantial African demand for it confronts sharp white resistance. Id. 
even "counterrevolutionary" as crime control. This concern becomes even more readily understandable in light of the facts about crime in South Africa. South Africa is a very dangerous country. Political violence, particularly in the last years of apartheid, has taken many thousands of lives. Nonpolitical violence has taken even more. In fact, South Africa's murder rate is one of the highest in the world-perhaps five times higher than that of the United States. ${ }^{122}$ Its rate of rapes may be the highest in the world. ${ }^{123}$ A great deal of South African crime is committed by Africans, a fact that reflects both widespread economic deprivation and, in all likelihood, the illegitimacy of South African law in the eyes of many, especially young, Africans. But Africans themselves appear to be the principal victims of South African crime. ${ }^{124}$ They are also the people most in need of police protection in South Africa, and most in need of whatever impact courts can make on the problem of crime. ${ }^{125}$ For a number of crimes, including murder, rape, and aggravated and common assault, the bulk of the cases heard in the

122. A recent newspaper article reports that South Africa has "an estimated 20,000 killings each year." Keith B. Richburg, "S. Africans Struggle to Cope with a 'Society in Stress'; Violence Creates a Heavy Mental Health Burden," Washington Post, 4 Sept. 1993 (available on NEXIS). In 1991, according to official statistics, there were 14,693 reports of murder. Hansson, 1992 S. Afr. Crim. Just. at 323. Most of these murders are not political; in 1991, for example, there were about 2,840 "[d]eaths as a result of political conflict in South Africa." Id. at 318. With a population estimated at $42,793,000$ (see U.S. Bureau of the Census, Statistical Abstract of the United States: 1993 at 841, table 1374 (1993)), 20,000 annual killings in South Africa would represent a homicide rate of 46.7 per 100,000 people. The rate in the United States in 1993 was 9.5 per 100,000. Federal Bureau of Investigation, Uniform Crime Reports for the United States 1993 at 13 (1994).

123. According to official statistics, there were 22,765 reports of rape and attempted rape in 1991. Hansson, 1992 S. Afr. Crim. Just. at 323. According to one calculation, in 1989 South Africa had almost 65 rapes per 100,000 people; the Unired States rate in 1988 was 37.6 per 100,000. Howard Witt, "S. Africa Takes on Tone of Wild West," Chicago Tribune, 19 March 1990 (available on NEXIS). There have been charges that the true rate in South Africa is even higher. Chris Erasmus, "Statistics Show Nation Is Armed, Dangerous," Gannett News Service, 14 Dec. 1991 (available on NEXIS).

124. In 1991, 2,681 people were convicted of murder in South Africa.. Of these, 2,577 were black. Of the victims, 2,510 were black. Hansson, 1992 S. Afr. Crim. Just. at 323 n.68. (Whites appear to have been more likely-at least in the eyes of the law-to commit, or to suffer, "culpable homicide," a lesser offense. In 1991, 3,051 people were convicted of culpable homicide, including 1,642 blacks; 1,640 of the victims were black. Id. at n.69.) In the same year, 4,661 people were convicted of rape or attempred rape; 4,496 of them were black and 4,418 of the victims were black as well. Id. at $n .72$. The great majority of those convicted of aggravated assault and common assault, and of their victims, also appear to have been black. Id. at nn.70, 71. This pattern dissolves, not surprisingly, with the crime of housebreaking, though even here many convictions are obtained in cases where blacks were victimized; of 35,930 convictions for this offense in 1991, 15,606 involved whites' residences, 8,989 blacks' residences and 10,956 "business and state premises." Id. at 324 n.84.

125. In one study, based on personal interviews with about 1,954 Africans in the Pretoria-Witwatersrand-Vereeniging (PWV) area, a heavily urban region, only $17.7 \%$ of Africans surveyed said that they felt very safe, or fairly safe, alone at night in their neighborhood. In contrast, $36.9 \%$ of Coloureds, $51.8 \%$ of Indians, and $67.6 \%$ of whites felt these levels of safety. Rita Esterhuysen (Senior Researcher), Perceptions of and Attitudes toward Crime, the Law and Components of the Criminal Justice System: A Comparison between Groups 15 (Human Sciences Research Council, 1984) ("PWV Study"). (This study is in Afrikaans; I rely on excerpts very kindly translated for me by Dr. Lorraine Glanz.) 
South African courts appear to involve African victims (and African perpetrators).

As a result, it is quite clear that many, if not most, Africans do take the issue of crime very seriously indeed. In Markinor's 1981 poll, more urban Africans (46\%) said that "maintaining order" should be the aim of the country than chose any other option, including "giving the people more say in important governmental decisions." 126 That result no doubt reflected Africans' understanding that there was very little they could realistically hope to get from the government of that day. Even in 1990, however, when urban Africans placed democratization and the economy ahead of law and order, ${ }^{127} 51 \%$ named a law and order concern as one of the two most important goals for the country. ${ }^{128}$ Africans themselves express dissatisfaction over the protection they receive, ${ }^{129}$ and many endorse harsh measures to try to stem the disorder from which they suffer. ${ }^{130}$

126. Markinor 1981 at 88 (cited in note 51). Only $29 \%$ of urban Africans polled said that "giving the people more say" should be the aim of the country. Id.

127. Markinor 1990 at 147 (cited in note 56).

128. Id. at 150. I follow Markinor 1990 at 148 , in including support for a strong defense force as a law and order position; South Africa's military has played a significant domestic role.

129. In surveys in 1983 and 1988 , only $31 \%$ and $35 \%$ of Africans, respectively, said they were satisfied, or very satisfied, with "security against crime." Moller, 7 (1) Indicator SA at 44 (cited in note 20). Similarly, according to a report in 1990, "[a] recent survey by Natal University said $35 \%$ of blacks feel they have little or no protection against crime." Rodney Pinder, "Tourist Killing Fuels Fear of Jungle Law in South Africa," Reuter Newswire Africa (31 Oct. 1990) (available on WESTLAW). In another survey, conducted in January 1988 and consisting of interviews with 677 adults in KwaMashu and Umlazi, $35.3 \%$ of the respondents felt that "your local police" were "doing a good job ... of maintaining law and order," and 21.4\% felt the police were doing an "average job"; $31.2 \%$ felt the police were doing a "poor job." KwaMashu/Umlazi Study at 189, 222 (cited in note 90). In the same survey, 43.3\% felt there were not enough policemen active in their area, somewhat more than felt either that the number of police was about right $(25.3 \%)$, or that it was too large (16.2\%). Id. at 223. In still another survey, $85.5 \%$ of Africans surveyed in the PWV region agreed or strongly agreed that "[t]he law ought to prevent crime more effectively," while just $31.0 \%$ felt that the South African Police were doing "well" or "very well" in maintaining law and order. PWV Study at 23,34 (cited in note 125).

130. In a November 1992 survey of 100 Africans in the Natal areas of Umlazi and Clermont, $60 \%$ or more of the respondents endorsed the death penalty for "shooting," "stabbing," murder and rape. Daniel Nina \& Stavros Stavrou, Research on Perceptions of Justice: Interaction between State Justice and Popular Justice (Durban, April 1993) ("Nina \& Stavrou, Research on Perceptions"). A more recent national poll (perhaps only of urban or metropolitan residents) similarly finds that $49 \%$ of blacks support retention of the death penalty, while $34 \%$ support abolition and 17\% "abstained." See "White South Africans Want Death Penalty Retained," Agence France Presse, 4 April 1995 (available on LEXIS). This support for the death penalty is particularly startling because both Inkatha and the African National Congress had proposed to prohibit capital punishment in a future South Africa. See Constitutional Committee of the African National Congress, ANC Draft Bill of Rights art. 2(3) (Preliminary Rev. Version, Feb. 1993); The [Proposed] Constitution of the State of KwaZulu/Natal art. 18(a) (n.d.; released Dec. 1992).

In the KwaMashu/Umlazi study (at 223), 38.5\% of the respondents felt that on the whole criminal sentences were too lenient; $30.7 \%$ viewed them as about right; and only $11.0 \%$ saw them as too severe. A modest plurality of the respondents (32.3\%) also felt that the local police were "on the whole . . to to lenient ... in their actions against suspects" 
In parts of South Africa, where relations between police and community have collapsed, the need for some sort of order presses Africans to accept the authority of often arbitrary people's courts or similar entities. Bill Keller of the New York Times reported in 1993 on a chilling example of this breakdown of formal law and order. Keller recounts the story of a woman who told "township vigilantes," after one of them announced their intention to "discipline" her son, that " $[t]$ he one thing I won't stand for, I don't want fire on my son. You can kill him, but do not burn him." In fact her son was hacked and burnt to death. Keller comments:

In Tembisa, as in many black townships where the police are regarded as an indifferent force, if not hostile, de facto law enforcement consists of a network of street committees loosely aligned with the African National Congress. They may intervene in anything from a domestic squabble to a killing.

The committees are nominally run by adults, but in practice it is the swaggering teen-agers who hold the balance of power.

Often it is hard to distinguish between the vigilantes and the outlaws, since both carry guns, salute one another as "comrade" and mimic the rituals of justice.

But Mrs. Mphahlele [the mother of the victim] respects the system for the limited protection it affords her and because, unlike the whiterun Government, it is a system in which she has standing. ${ }^{131}$

(emphasis in original); $28.7 \%$ felt the police treatment of suspects was "just about right," and $21.9 \%$ felt the police were on the whole "too strict." Id. at 222.

Similarly, in the PWV Study (at 23), $86.4 \%$ of Africans agreed or strongly agreed that "[t]here would be less crime if our laws were stricter"; $40.9 \%$ believed that in general the police were too lenient with offenders, while only $18.0 \%$ saw the police as too harsh (at 35); $46.7 \%$ agreed or strongly agreed that the death penalty was "the best preventive measure against crime" (at 43); and 63.9\% felt that living conditions in prisons should be made more difficult (at 61). (At the same time, however, $51.6 \%$ believed that fines should be used more often instead of imprisonment, and $56.1 \%$ also felt that community service orders should more often replace imprisonment (at 44-45); in a similar vein, $53.6 \%$ felt that the emphasis in sentencing should be on rehabilitation, rather than either on punishment or on a mix of punishment and rehabilitation (at 61). The seeming inconsistencies between these sentiments and the more punitive responses noted earlier raise some doubts about the meaning of this survey's results.)

131. Bill Keller, "A Short, Violent Life in South Africa," N.Y. Times, 17 Nov. 1993, at A3. Another account reports a survey finding that "nearly 79 percent of the residents of Mamelodi saw neighbourhood vigilantes as the best solution to the problem of violent crime in the community." John Hund \& Malebo Kotu-Rammopo, "Justice in a South African Township: The Sociology of Makgotla," 16 Comp. \& Int'l L.J. S. Afr. 179, 181 (1983), citing R. K. Mabusela, ed., Mamelodi: Progress in Community Work 21 (National Institute for Crime Prevention and the Rehabilitation of Offenders, 1980). Hund and Kotu-Rammopo observe (at 181) that the "main duties [of the police in this township] appear to be confined to protecting the property of the administration board, enforcing influx control laws, and allegedly offering protection services to the operators of illegal shebeens or taverns with whom it is reported they act as collaborators." 
But surveys suggest that despite their deep distrust for the formally constituted authorities, many Africans continue to resort to them, at least in cases of serious nonpolitical crime. The most striking evidence of this comes from a "perception study" done in the area of Pietermaritzburg, a region in South Africa racked by especially ferocious conflict between supporters of the African National Congress and adherents of the Inkatha movement. ${ }^{132}$ In this conflict, the police were seen as blatantly biased in favor of Inkatha. ${ }^{133}$ More than $60 \%$ of the people interviewed characterized the police as "hostile and aggressive" or "indifferent and remote."134 When asked to characterize the work of the police on nonpolitical crimes, however, $38.8 \%$ called it good or excellent and another $23.1 \%$ considered it "average."135 Moreover, despite their sometimes harsh assessments of the police, $66 \%$ of the people polled reported that they had in the past "laid charges at their nearest police stations on a variety of complaints," and $66.5 \%$ "said they would readily and willingly report an incident or lay a complaint at a police station." 136 The author of the study comments: "This willingness on the part of respondents to approach the police for help is to be welcomed in view of

132. Saras Jagwanth, "Policing of the Conflict in the Greater Pietermaritzburg Area: A Perception Study," 9 S. Afr. J. Hum. Rts. 536 (1992). This study was based on personal interviews, conducted in Zulu, with 364 people. Slightly over half were ANC supporters, and just over a fifth were affiliated with Inkatha. All those interviewed lived in two areas, one "ANC dominated," the other of mixed politics. The researchers' efforts to interview people in a third, Inkatha-dominated area were rebuffed by the local authorities. Id. at 537-39.

133. For a stark account of the conflicts around Pietermaritzburg, an account which essentially agrees with this perception of police bias, see Matthew Kentridge, An Unofficial War: Inside the Conflict in Pietermaritzburg (1990). In the Pietermaritzburg perception study, $71.2 \%$ of the people interviewed felt the police had displayed partiality; only among supporters of Inkatha-widely viewed as the beneficiaries of this partiality-did a majority (55.3\%) view the police as impartial. Jagwanth, 9 S. Afr. Hum. Rts. at 546.

134. Id. at 550. ANC supporters were the most critical, Inkatha supporters the least. Id.

135. Id. at 549 . Of those interviewed, $4.7 \%$ rated the police as excellent, $34.1 \%$ as good, $23.1 \%$ as average, $32.4 \%$ as poor, and $5.8 \%$ answered that they didn't know. Id. The meaning of the "average" rating is ambiguous, but in the context of the other choices offered to the respondents it seems plausible to understand "average" as meaning roughly the same as "adequate."

In another question, respondents were asked to rate a number of different police agencies on a 1-5 scale, with 1 defined as "very good," 2 as "good," 3 as "average," 4 as "poor," and 5 as "very poor." Of those interviewed, $47.7 \%$ rated the South African Police as below average (" 4 " or " 5 "); $59.6 \%$ so evaluated the KwaZulu Police; and $62.4 \%$ expressed this view of the "kitskonstabels" (particularly poorly trained police used in black communities). But only $30.9 \%$ took so bleak a view of the "municipal police," and just $29.7 \%$ so evaluated the South African Defence Force or SADF (that is, the army); $41 \%$ saw the SADF as "very good" or "good." Id. at 553. The author of this report seems hesitant about the meaning of these responses and says that the data are "used principally for comparative purposes." Id. But the respondents' answers seem to entail not just a belief that the SADF, in particular, was less bad than other "law enforcement" agencies-certainly an understandable comparative assessment-but also, and perhaps more surprisingly, that the SADF was quite "good."

136. Id. at 551. A related table suggests, however, that the respondents affirmed that they were "willing to approach the police for assistance"-not as enthusiastic a statement as that they would "readily and willingly report an incident or lay a complaint at a police station." Id. at 552. 
the warnings by many academic writers as well as community members that the lack of confidence in the police will lead to self-help and anarchy."137

It might be objected that resort to the police is no indication of any belief in the legitimacy of the police or of the latger legal system. In Tom Tyler's careful survey research study of legitimacy in Chicago, the "primary determinant" of whether people said they would go to the police or to court to resolve problems was their evaluation of the authorities' performance. "In contrast, the legitimacy of the authorities had only a minor influence."138 Moreover, it might be argued that Africans' desire for crime control is not enough to persuade them to accord legitimacy to an unjust system. In the words of Don Nkadimeng, a lawyer, law teacher, and leader of a radical black political group, the Azanian People's Organization, "I would imagine that what black people want here is what people everywhere else want .... They want order . . . but they don't want order at the expense of justice." 139

Strong as pragmatic explanations are, there is some reason to believe that they do not fully capture Africans' responses to their legal system on the question of crime control. To be sure, the pragmatic calculations favoring resort to the state's law enforcement system may be compelling, for although the state no longer has a monopoly on the instruments of force in South Africa, it does have by far the most elaborate apparatus for the control of crime. The importance of such practical calculations is suggested by a survey of 100 Africans in two townships near the city of Durban. ${ }^{140}$ In this study, respondents were asked which legal authorities they would take various crimes to. Of the respondents, $60-70 \%$ said that they would take murder, shooting, rape, burglary, and robbery to the police rather than to a variety of other possible entities. ${ }^{141}$ Only on three offenses, physical assault, domestic violence, and witchcraft, did the respondents identify community

137. Id. at 553. For even more explicitly positive views of the police, expressed by African youth in a nationwide survey, see text at note 91 supra.

138. Tyler, Why Obey Law 239-40 n.7 (cited in note 11); see Sarat, 11 Law \& Soc'y Rev. at 5 (cited in note 113).

139. Interview with Don Nkadimeng, 2 Nov. 1994, transcript at 17 . A number of black lawyers with whom I spoke, though not all, found this "crime control" theory of legitimation unlikely. Thus Mahomed Navsa, an advocate at the Legal Resources Centre in Johannesburg who headed the LRC's constitutional litigation unit, responded that "levels of resistance would never have escalated to the point that they did" if this theory were correct. He further argued that it would have been extremely hard for people to adopt the stance of seeing the system as helpfully controlling others, since "it was such an all-pervasive system which cut across everyone's lives, if you were African, it touched you, you couldn't escape it." Interview with Mahomed Navsa, 7 Nov. 1994, transcript at 11. Even so, the grounds for inferring that such thinking did find a place among "conservative" Africans seem to me to be persuasive.

140. Nina \& Stavrou, Research on Perceptions (cited in note 130).

141. In addition, $59 \%$ would have taken theft to the police, and $49 \%$ would have taken "stabbing." Id. at 9, 22-27. In contrast, Hund and Kotu-Rammopo, 16 Comp. \& Int'l L.J. S. Afr. at 183 (cited in note 131) comment: "Although we have no reliable survey data on the matter, it seems clear that the vast majority of blacks living in townships do not turn to the official court structure for help in processing their claims or for redressing their grievances." Perhaps violent crimes are an exception to this generalization, or perhaps Hund and Kotu- 
groups or people as their preferred choice. ${ }^{142}$ Whatever their choices, however, the reasons the respondents offered for their choices seem to have been very pragmatic. ${ }^{143}$ Certainly their choices did not come primarily from a belief in the fairness of South African law; over two-thirds believed that the laws enforced by the police were unfair, at least under certain circumstances, and over half held the same view of the laws enforced by the magistrate. ${ }^{144}$

This same survey implies, however, that Africans might also recognize a measure of legitimacy in the legal system. According to the survey, "[r] espondents were asked to list what organization, authority, groups of people or individuals are symbols of the judicial system. No limit was imposed on the number of responses allowed from individuals." 145 "This question is very ambiguous; one might imagine, for example, that it would only elicit the respondents' understanding of what the current system of justice consisted of, rather than any hint of their views of whether justice was actually being done in that system. But the respondents' answers, as set out in table 3 , seem to reflect some flavor of evaluation as well as description, and if that inference is correct, then it is striking that the respondents felt as disposed as they did to name elements of the current legal system as symbols of the judicial system or justice.

In this survey respondents were also asked whether each of a series of entities had "the right to enforce the law and protect the people." Again, the meaning of the question is ambiguous; perhaps those who answered it felt they were being asked to make a moral judgment, or perhaps they felt they were being asked for a statement of positive law. Clearly at least some respondents took moral considerations into account, however, for some answered not that the body in question did or did not have the right to enforce the law, but that it should. Table 4 presents the responses, combining those who answered that a given body did have this right and those who said that it should have the right.

Rammopo's observation is unqualifiedly true in some areas-Tembisa, for example (see text at note 131) - and not in others.

142. Nina \& Stavrou, Research on Perceptions 11-12. Only 27\% would have reported physical assault to the police, just $6 \%$ would have reported domestic violence, and $3 \%$ would have reported witchcraft. Id. at $24,25,27$.

143. Id. at $11,22-27$.

144. Id. at 34. The distinction in assessments of the laws enforced by the police and those enforced by the magistrate is intriguing, since presumably the laws in question were actually the same. The difference in perception, then, seems to be the result of a difference in assessment of the enforcing agency, and so we can conclude that these 100 survey respondents had a modestly more charitable view of the fairness of the courts than they did of the police. This finding echoes the distinctions drawn by Africans nationwide, as discussed earlier. See text at notes 73-75 supra.

145. Id. at 8 . It appears that the actual question was slightly different from this paraphrase and asked "what kind of symbols represent justice," rather than what symbols represented the "judicial system." Id. at 21 (emphasis added). 
TABLE 3

What Kind of Symbols Represent Justice?

\begin{tabular}{lc}
\hline \multicolumn{1}{c}{ Symbol } & Response (\%) \\
\hline Courts & 72 \\
Police & 64 \\
Civic associations & 60 \\
Lawyers & 54 \\
People's marshals & 53 \\
Judges & 49 \\
People's courts & 37 \\
Tribal authorities & 32 \\
Warlords & 16 \\
Other & 13
\end{tabular}

SOURCE: Nina \& Stavrou, Research on Perceptions 8 (cited in note 130).

\section{TABLE 4}

Authorities with the Right to Enforce the Law

\begin{tabular}{lcc}
\hline Authority & Has Right (\%) & Has No Right (\%) \\
\hline Police & 84 & 16 \\
Lawyers & 83 & 17 \\
Magistrates/courts & 81 & 19 \\
Civic associations & 70 & 30 \\
Tribal authorities & 64 & 36 \\
People's courts & 58 & 42 \\
Warlords & 11 & 88 \\
\hline
\end{tabular}

SOURCE: Nina \& Stavrou, Research on Perceptions 12 (cited in note 130).

These answers suggest, albeit ambiguously, that Africans who saw great unfairness in their legal system nonetheless still saw that system as linked to justice, both symbolically and in terms of its entitlement (positive or moral) to enforce the law. Some flavor of legitimacy, I suggest, emerges from these responses and helps to support the inference that Africans' acute need for law enforcement still provides them with a basis not just for using the legal system but also for modestly legitimizing it. Other studies as well have elicited a similar, puzzling mixture of positive and negative assessments by Africans of the justice of their courts, in particular with respect to crime. ${ }^{146}$ The

146. The respondents in the $1988 \mathrm{KwaMashu} /$ Umlazi Study (cited in note 90) also offered striking illustrations of the approval that some black South Africans accord to their legal system. Of those surveyed, $62.6 \%$ agreed that "[t]he law punishes trespassers and protects lawabiding people"; only $14.4 \%$ disagreed, while $23.0 \%$ were "neutral." Id. at 225 . Similarly, $40.9 \%$ agreed that "liin this country nobody will be sentenced to prison without good reason"; $30.9 \%$ disagreed, while $28.2 \%$ were neutral. And $40.0 \%$ denied that "[t]he police arrest many 
ambivalence of these assessments certainly should not be ignored, but it would equally be a mistake to distegard only the positive evaluations that Africans offer. This very ambivalence seems well captured in the idea that Africans are according their legal system a measure of legitimacy. ${ }^{147}$

innocent people," while only $28.3 \%$ agreed with this statement, and $21.8 \%$ were neutral. Id. at 224.

These respondents may have been unusually conservative in their general orientation, but these suggestions of legitimacy cannot simply be written off as aberrations, for in response to other questions some of these same respondents demonstrated that they were capable of considerable cynicism about the legal system. $42.2 \%$ agreed that "[p]olice officers do not care what happens to you after you have been arrested," and 38.5\% were neutral; only 19.3\% disagreed. Only 30.8\% agreed that "[m]agistrates are honest and kind-hearted" (44.8\% were neutral and $24.4 \%$ disagreed); similarly, only $29.3 \%$ agreed that "[i]n the courts all people are treated justly" ( $43.3 \%$ were neutral and $27.4 \%$ disagreed). Id. Finally, and in the same vein, only $24.6 \%$ agreed that "[c]lourt verdicts are always just," while $48.2 \%$ were neutral and $27.2 \%$ disagreed. Id. at 225. Even these levels of approval are startling to an outside observer, and remind us of just how conservative some African opinion is. (The large percentages expressing neutrality, however, are puzzling; were these respondents simply unsure, see id. at 205, or were they being discreet?) Perhaps more important, however, some of these respondents were evidently able to combine skepticism or reserve about the courts and the police with some measure of what appears to be respect for them. The resulting answers are not always mutually inconsistent, and, when they are, some part of the explanation may lie in respondents' misunderstanding of the questions or strategic responses to them. But it seems reasonable to infer that another part reflects actual ambivalence and to remember that legitimation can be ambivalent, and yet still exist.

So, too, in another survey, $59.6 \%$ of Africans agreed or strongly agreed that "[a]ll are equal in the eyes of the law," $48.7 \%$ that "[a]ll people are treated fairly by the courts," $60.2 \%$ that "[n]o one will be sent to prison in this country without good reason," $48.0 \%$ that "[m]agistrates are honest and compassionate," and 55.4\% that "[c]ourt judgments are always just." PWV Study at 23, 41, 42 (cited in note 125). At the same time, 52.1\% believed that "Im]any people in prison are actually not guilty of the crime for which they are being punished." Id. at 42.

Finally, in a survey of youth attitudes by the liberal agency CASE, polling found that a small fraction of young people of all races-between a tenth and a fifth-believed that people sent to prison for crimes of fraud, assault and rape were "victims of the system." (African youth were not more likely, and with respect to fraud were actually less likely, to hold these views than were young people of other groups.) Everatt, "A Violent Generation?" at 1-2 (cired in note 91). Though this brief summary of the poll's findings does not spell the point out, it would appear that a greater fraction of young people of all races must have expressed contrary views.

147. One further indication that Africans in South Africa are taking legitimacy into account in their use of the police is the admittedly scanty evidence from some of these same surveys that Africans did acknowledge an obligation to obey the law. In the PWV Study at $24,47.7 \%$ of the Africans surveyed agreed or strongly agreed that "[r] he law should be obeyed at-all times," though $68.5 \%$ of the respondents also agreed or strongly agreed that "[a] person need only obey those laws that seem to be reasonable." Of those surveyed, $67.4 \%$ disagreed or disagreed strongly with the statement that "ii]t is all right to transgress the law as long as one does not get caught," and in the KwaMashu/Umlazi Study at 225, $82.0 \%$ disagreed with a similar or identical proposition.

Markinor's surveys, somewhat similarly, found that although Africans did offer a degree of approval for various illegal acts, on average they still leaned toward viewing crimes-even such arguably political acts as political assassination, fighting with police, or "claiming state benefits which you are not entitled to"-as unjustified. See Markinor 1981 at 78 (cited in note 51); Markinor 1990 at 37 (cited in note 56).

One exploratory study of predominantly African offenders (described as "juveniles" though many were over 20), most of whom were serving sentences for violent crimes, found that considerable portions even of this group showed some support for fidelity to the law (and 
What could account for this degree of legitimation? The fact that resort to the legal system can get some results is not irrelevant, but in his careful study of legitimation in the United States, Why People Obey the Law, Tom Tyler demonstrates persuasively that people's views of the legitimacy of the legal system are affected not only by whether they get the results they hope for in their encounters with this system but also by whether they feel they have been treated in a fair manner by it. ${ }^{148}$ Fairness is a matter both of outcome and of procedure, but Tyler concludes that procedural justice is "the key normative judgment influencing the impact of experience on legitimacy."149 Tyler also suggests, however, that a strategy of legitimation by procedure cannot ultimately be successful if the actual outcomes are stubbornly unsatisfactory. ${ }^{150}$

Tyler's work, then, directs our attention to perceptions of fairness in procedure and in results. The same factors may help resolve a debate over Douglas Hay's well-known argument that the 18th-century English legal system won deference by deftly mixing ferocity and elite benevolence. ${ }^{151}$ In response to this argument, which might be described as an argument for legitimation through seemingly fair procedures, John Langbein argued: "The criminal law and its procedures existed to serve and protect the interests of the people who suffered as victims of crime, people who were overwhelmingly non-elite." 152 Perhaps we can understand the debate between Hay and Langbein from this perspective: the display of elite magnanimity that Hay sees as integral to the English criminal law may have owed its ideological success in part to the fact that the day-to-day business of the courts provided "non-elite" people with a measure of concrete protection and what they saw as fair outcomes. The procedural justice of the South African legal system is far from perfect, but this system may well have offered enough appearance, and even reality, of fair procedure and concrete protection to earn a measure of legitimacy.

some approval of the existing legal system). For example, $59.9 \%$ disagreed with the proposition that "[i]t is all right for a person to break the law as long as he doesn't get caught," and $30.3 \%$ agreed that "[t]he present court system treats everybody justly." However, $58.1 \%$ felt that "[m]any [of] the people in prison are actually not criminals but victims of the system," and $46.1 \%$ felt that "Africans who violate the law should be punished by people's courts and not by the present criminal justice system." Evanthe Schurink \& Willem Schurink, "Addressing Crime amongst SA's Marginalised Youth," 4 (2) Info. Update 47, at 53 (1994).

148. See Tyler, Why Obey Law 94-112 (cited in note 11).

149. Id. at 162 .

150. See id. at 30, 106-7, 147, 164.

151. Douglas Hay, "Property, Authority and the Criminal Law," in Douglas Hay, Peter Linebaugh, John G. Rule, E. P. Thompson, \& Cal Winslow, Albion's Fatal Tree: Crime and Society in Eighteenth-Century England 17 (1975). For a similar view of the impact of the power of Southern slaveholders, see Eugene Genovese, Roll, Jordan, Roll: The World the Slaves Made 40 (1976).

152. John Langbein, “Albion's Fatal Flaws," Past \& Present, Feb. 1983, 96, at 97. 
It will not do to overstate the procedural fairness of South Africa's courts. ${ }^{153}$ Until the very last years of apartheid, the judges of the highest courts, the "Supreme Courts," were all white (and almost all male), and the vast majority of South Africa's magistrates, who preside over the lower courts, were white too. ${ }^{154}$ Senior police officers would also have been entirely, or almost entirely, white. Only about a tenth of South Africa's lawyers are black. ${ }^{155}$ In many, many cases black South Africans have not been represented by counsel when they faced criminal charges, because no comprehensive system of legal aid to indigent defendants exists. ${ }^{156}$ Because South Africa's official legal languages have been Afrikaans and English, many Africans go to trial in courtrooms where they must rely on interpreters to understand the proceedings; interpreters are provided by the state, but their sometimes troubling performance can inject a further source of unfairness into the proceedings. ${ }^{157}$ Such racial discourtesies as referring to white witnesses as "Mr." or "Mrs." while addressing black witnesses by their first names may still not have died out. ${ }^{158}$ And whatever the courts' claims to procedural fairness, they are further undercut by substantive injustice-by laws that have explicitly or effectively applied only to blacks ${ }^{159}$ and by discrimination in sentences. ${ }^{160}$

For lawyers, one of the most damning charges against the fairness of the South African courts has distinguished between the Supreme Courts and the magistrates' courts and suggested that the latter are specially subject to state control. This charge has considerable force, even though until the nonracial elections of 1994 all the judges of all these courts were appointed by the government. The difference is that judges of the Supreme Courts

153. Nor, it deserves emphasis, should we overstate the quality of the crime control results the South African legal system delivers. Africans are poorly rather than well protected against crime.

154. See note 117 supra.

155. See D. Mokgatle, "The Exclusion of Blacks from the South African Judicial System," 3 S. Afr. J. Hum. Rts. 44, 46 (1987).

156. In 1991, 683,641 people appeared in court "on charges of serious offense without legal representation." Hansson, 1992 S. Afr. Crim. Just. at 326 (cited in note 117). For commentary on this problem, provoked by a decision of South Africa's highest court declining to recognize a right to state-appointed counsel, see the articles by Dennis Davis, David McQuoid-Mason, N. C. Steytler, and J. R. Midgley \& Clive Plasket, in "Focus on Rudman," 8 S. Afr. J. Hum. Rts. 90-125 (1992).

157. See N. C. Steytler, "Implementing Language Rights in Court: The Role of the Court Interpreter," 8 S. Afr. J. Hum. Rts. 205 (1992).

158. See C. R. M. Dlamini, "The Influence of Race on the Administration of Justice in South Africa," 4 S. Afr. J. Hum. Rts. 37, 46 (1988).

159. With the beginning of the dismantling of apartheid, fortunately, the most egregious of these-such as the Group Areas Act or the pass laws-were repealed. Even now, however, facially neutral laws may have decidedly nonneutral impacts; laws seeking to stem "squatting" by otherwise homeless people, e.g., in practice apply almost exclusively to blacks. For an early overview of South Africa's explicitly or effectively race-based criminal legislation, see Albie Sachs, Justice in South Africa 164-74 (1973) ("Sachs, Justice in South Africa").

160. For some glaring examples, see Dugard, Last Years 107-10 (cited in note 1). 
have been appointed almost exclusively from the ranks of advocates (barristers), in particular from among those advocates who have become "Senior Counsel"-in short, from an elite within an elite, and moreover from an elite whose professional culture puts a considerable premium on independence of mind. ${ }^{161}$ Magistrates, in contrast, are civil servants, and perhaps are much more subject to implicit or even explicit promptings by their superiors. ${ }^{162}$ Since the magistrates handle far more cases than the judges of the Supreme Courts, the import of this criticism is that the bulk of Africans in the courts receive tainted justice. ${ }^{163}$

Yet there is a case to be made for the proposition that some Africans see the South African legal system as providing fair procedures (and fair results). Much of African opinion, as I have already suggested, is by no means radical, and survey evidence suggests that many Africans do in fact see the legal system as fair. In one study, almost a quarter of the African respondents in two KwaZulu/Natal townships agreed that "[c]ourt verdicts are always just," and slightly more agreed that "[i]n the courts all people are treated justly." 164 In another survey, respondents were even more enthusiastic about the fairness of the courts. In this study, $55.4 \%$ of Africans agreed or strongly agreed that "[c]ourt judgments are always just," $59.6 \%$ that "[a]11 are equal in the eyes of the law," and $48.0 \%$ that "[m]agistrates are honest and compassionate."165

The imperfect justice of the state's courts, moreover, must be weighed by those who assess it against the available alternatives. Africans in South Africa have long traditions of maintaining and using judicial bodies outside the purview of the state, ${ }^{166}$ but in recent years the most publicized (at least in white-owned media) and the most notorious have been the "people's courts." These institutions, conceived in struggle and initially operated with great idealism, have shown an alarming tendency to deteriorate quickly into quasi-criminal operations. ${ }^{167}$ They have also been the domain of the

161. See Ellmann, Time of Trouble 212-30 (cited in note 2).

162. See id. at 226 n. 325 .

163. One tantalizing piece of survey research suggests, moreover, that black South Africans may have been well aware of the inferior quality of the magistrates' justice. Dennis Davis found in "a pilot study of 100 black South African respondents living in Langa, Nyanga, and Cape Town conducted in $1986 \ldots$ that approximately $40 \%$ of the sample considered that they could receive a fair trial in the Supreme Court. Few, if any, felt the same of the Magistrate Courts." Davis, 18 Soc. Just. at 77 (cited in note 92).

164. See note 146 above, describing results of the KwaMashu/Umlazi Study.

165. See note 146 above, describing results of the PWV Study.

166. Sandra Burman \& Wilfried Schärf, "Creating People's Justice: Street Committees and People's Courts in a South African City," 24 Law \& Soc'y Rev. 693, 695-96 (1990).

167. For a vivid case study, see id. at 721-34. "People's courts" had a radical political aura, but more conservative political groupings may also create courts that operate in disturbingly coercive ways. For an example, see the discussion of the Vukani Vulimehlo People's Party, in whose court "the judge-interrogator was ... known by the nickname of 'satan,'" in Hund \& Kotu-Rammopo, 18 Comp. \& Int'l L.J. S. Afr. at 191-93 (cited in note 131). Similarly, Jeremy Seekings has commented on the troubling features of the relatively conservative 
young-and not all Africans are young, nor are all by any means content with the impact of youth mobilization on traditional African respect for elders. ${ }^{168}$ Though community justice has deep roots in African communities, and may well be an important aspiration of Africans for a postapartheid era, dissatisfaction with the forms of community justice characteristic of the past decade may have played a part in Africans' partial acceptance of the state's legal system. ${ }^{169}$

\section{Day-to-Day Concerns as Sources of African Legitimation: Resolving Civil Legal Problems}

In describing a conservative paradigm of African thinking, I have not meant to suggest that the substantial number of people who shared "conservative" perspectives were indifferent to the injustice of apartheid. On the contrary, the injustice of apartheid was all around them, in the dangerous conditions of their daily lives and in the tremendous force of economic deprivation to which they were constantly subjected. I have argued, however, that the legal system might have gained some measure of legitimacy from its provision of a response-poor as that response was-to the problem of

community courts, or makgotla, of Soweto, some of which, he says "earned a reputation for arbitrary procedure, violent policing, and excessive sentences. Such practices provided ready opportunities for vengeance rather than justice. The press were filled with reports on the arbitrariness of makgotla, which seem to have become private and paramilitary rather than civil and judicial institutions, operating to advance the immediate interests of their leaders." Seekings, "Visions" at 5 (cited in note 105).

Condemnation of the people's courts is not universal. Pansy Tlakula and Tom Lediga of the Black Lawyers Association both emphasized to me that some people's courts, but not all, had had problems. Tlakula \& Lediga interview, 7 Nov. 1994, transcript at 5 (cited in note 29).

168. See Burman \& Schärf, 24 Law \& Soc'y Rev. at 730-31. Hund \& Kotu-Rammopo describe a community court organized by older people in an effort to control the young, but ultimately deprived of its means of coercion by a successful lawsuit brought in the formal court system by one of the young people whom it had subjected to corporal punishment. Hund \& Kotu-Rammopo, 18 Comp. $\&$ Int'l L.J. S. Afr. at 185-86. More recently Hund has commented that the relations "between the youth or the 'comrades' and the 'fathers' who represent establishment values" might best be characterized as "warfare." John Hund, "Formal Justice and Township Justice," in Hund, ed., Law and Justice in South Africa 203, 214 n.12 (1988).

169. Nina \& Stavrou, Research on Perceptions 28 (cited in note 130) found evidence both of Africans' desire for community involvement in the system of justice $(67.0 \%$ believe the community should "have a more active role in the dispensation of justice") and of Africans' dismay over the performance of the people's courts (at 8,11-12,15-16); see also table 3 above (respondents were twice as likely to characterize the "courts" as symbols of justice as they were to characterize "people's courts" this way). Sandra Burman offers evidence which suggests that in colonial days dissatisfaction with traditional systems of justice might similarly have led some Africans to resort to the white magistrates' courts. Sandra Burman, "Symbolic Dimensions of the Enforcement of Law," 3 (2) Brit. J.L. \& Soc'y 204, 210, 213 (1976); see Burman \& Schär, 24 Law \& Soc'y Rev. at 695. For a vivid account of vigilante justice in one township-and a reminder that some Africans preferred this form of justice, with all its flaws, to the state's institutions-see text at note 131 above. 
crime. It is possible that, especially after 1981, some measure of legitimacy might also have come from the increasing availability of legal responses to Africans' poverty and economic need.

Again, I do not mean to overstate what the law could do about the economic suffering Africans faced. It could not do much at all. But it could do something. An eviction might be forestalled. A pension payment might be extracted. An employee firing might be reversed. And as the $1980 \mathrm{~s}$ progressed, more and more Africans would have become aware of these possibilities. Some of the victories lawyers won became the subject of media attention. ${ }^{170}$ Another central force in making Africans aware of the law as a resource would likely have been the "advice centre" movement, which gathered steam in the early 1980 s, and it is important to briefly take account of this movement now.

I spoke about advice centres primarily with Thandi Orleyn, the director of the Johannesburg office of the Legal Resources Centre (LRC), and much of the account I give here is based on that conversation. Advice centres appear to be, essentially, paralegal offices, at least some of which are "backed up" by lawyers, who can guide the paralegals' work and take over the more complex matters that come into the offices. But a great deal of the work of creating the offices and staffing them has apparently been done by activists from community, church, and student groups, rather than by lawyers. ${ }^{171}$ It seems reasonable to infer, therefore, that potential clients who approached these offices often understood them as having a progressive political foundation. In any event, the number of people who used these offices appears to have been very great. Ms. Orleyn told me that each of the offices of the Legal Resources Centre's network sees about 10,000 people per year. ${ }^{172}$ The LRC's network consists of about 100 advice offices and appears to provide a measure of coverage to many parts, though probably not all, of the nation. ${ }^{173}$ At 10,000 matters per office, this network of 100 advice offices may be responding to about $1,000,000$ matters annually-and there are apparently many other advice offices not linked to the LRC. ${ }^{174}$ Not all the problems that clients bring to the advice centres are legal, and not all the legal problems can be fixed. ${ }^{175}$ But still it seems clear that the effective reach of law was extended to many people in the black population

170. Tom Rikhoto, for example, was on television. More generally, Mahomed Navsa observed that, especially in urban areas, "the thing was that victories were portrayed where there weren't any before. I think there was a greater sense of being able to use the law than before." Mr. Navsa went on to say that "I think people might have had a greater and better appreciation for the way the courts operated and greater sense that not everything is bad, but I think it must be qualified by the bigger picture," which he saw as decidedly bleak. Navsa interview, 7 Nov. 1994, transcript at 12 (cited in note 139).

171. See Orleyn interview, 10 Nov. 1994, transcript at 10 (cited in note 111).

172. Id. at 7-8. This figure is a "rough estimate."

173. Id. at $8-10$.

174. Ms. Orleyn mentioned an estimate of 9,000 advice centres nationwide. Id. at 7 .

175. Id. at 8,11 . 
of South Africa during the 1980s. It also seems reasonable to conclude, as I understood Ms. Orleyn did, that this movement had helped "make people aware of the law and to restore some of [their] confidence" in it. ${ }^{176}$

\section{The Role of Race in Legitimizing the Legal System}

The South African legal system under apartheid was run by whites. Judges, magistrates, and senior police officers were almost all white. Moreover, many Africans deeply mistrusted whites, for obvious and good reasons. ${ }^{177}$ Nevertheless, I was startled to hear repeated suggestions from people I spoke to in South Africa that some Africans might have preferred the official legal system to other possible methods of resolving disputes because the decision makers were white. ${ }^{178}$ Yet this is not a new observation in South Africa. On the contrary, Stephen Biko, the "black consciousness" leader who died in police hands in 1977, explained that it was a central insight of black consciousness that "the black man in himself has developed a certain state of alienation, he rejects himself precisely because he attaches the meaning white to all that is good, in other words he equates good with white. This arises out of his living and it arises out of his development from childhood."179

This preference for white decision makers could rest on such self-denigration, ${ }^{180}$ or it could arise from Africans' very practical assessments of as-

176. Id. at 12. Ms. Orleyn may have been focusing here on a particular recent development in connection with advice centres, but I understood her to take this view more generally as well.

177. On a 10-point scale, on which "10" meant complete trust, urban Africans' level of trust in whites in 1990 was 3.7, according to Markinor's polling. Markinor 1990 at 173 (cited in note 56). Apparently, their level of trust in other Africans (labeled as "blacks" in the poll) was 5.7.

178. These comments were typically made by lawyers or organizers (most of them black) about ordinary Africans, and it is possible that these perceptions in part reflect class and ideological gaps between elite observers and those whom they observed-although I believe the observers' suspicions make sense. Jotham Zwane, a rural activist, offered a contrasting view. He emphasized that some people would say they deferred to whites and whites' courts but that they did so because they were scared. "[T]he apartheid was very tough thing to make a man to agree although he [does] not agree. To force him to agree [to] any things because you can be killed and anytime." Interview with Jotham Zwane, 8 Nov. 1994, tape 2 transcript at 20. (This interview took place in Mr. Zwane's home in the Eastern Transvaal village of KwaThandeka. For a brief account of some of the remarkable events of Mr. Zwane's life of resistance to apartheid, see Geoff Budlender, "The Responsibility of Lawyers to Challenge Injustice," 40 Cleve. St. L. Rev. 475, 475-77 (1992).)

179. Bantu Stephen Biko, testimony at the 1976 subversion trial of nine blacks linked to the South African Students Organisation (a black consciousness group), as excerpted in Donald Woods, Biko 188 (1979). Brown v. Board of Education, 347 U.S. 483, 494-95 \& n.11 (1954), relies in part on a similar understanding of the terrible impact of American school segregation.

180. Pansy Tlakula of the Black Lawyers Association thought it probable that some people might defer in part to the legal system because it was a white system and earlier appeared to see force in the idea "that in this country ordinary people still regard to a very large extent 
pects of their daily life. Nomazizi Mtshotshoso, the Acting National Director of the National Association of Democratic Lawyers, told me that township people might prefer to have their case resolved by a magistrate rather than by a township leader in an informal African court, because they might "perceive [the magistrate] as someone who ... hasn't got a relationship with either ... party in the dispute, so in that sense they would regard him as impartial," even while being certain that in a case involving a conflict between whites and blacks, the white magistrate would favor whites. ${ }^{181}$ Moreover, self-denigration may shape what purports to be realistic assessment. As one unionist said to me, blacks have been taught to believe that "whites are naturally honest to justice and the truth, but blacks get influenced by personal relations." Another described the feeling that adjudication "that is done by white people ... is done by good people."182 Men and women affected by such thinking would paradoxically find the white domination of the judiciary a virtue. ${ }^{183}$

I do not at all mean to suggest that all Africans who think, in whole or in part, in conservative terms are expressing the taint of a belief in their own inferiority. What I have called the conservative paradigm is, again, made up of a number of different strands of thinking. These strands can reinforce each other, but they are not necessarily bound up with each other. Rather, the conservative paradigm encapsulates a somewhat diverse range of perspectives, which individually or in conjunction with each other may contribute to support for the South African legal system. Though there is no way to be sure, I suspect that conservative arguments such as these played a major part in the high confidence ratings the legal system received in 1981 - a time when political mobilization was blunted and Africans might well have been focusing primarily on the quotidian concerns of ordinary life in their communities. In the decade that ensued, other sentiments, reflected in the paradigms of the "speakers" and the "activists," may well have gained greater force in Africans' thinking. Yet it seems very unlikely that "conservatism" has been extinguished over these years, and entirely likely that it has continued to play a part in Africans' assessments of the South African legal system.

white people as being supreme." Tlakula \& Lediga interview, 7 Nov. 1994, transcript at 6-7 (cited in note 29).

Even more directly, Tom Nkadimeng told me that sometimes clients in his legal practice ask him if their legal problem seems too complicated, "Can you get me a white lawyer?" Nkadimeng interview, 2 Nov. 1994, transcript at 19 (cited in note 139).

181. Mtshotshosa interview, 7 Nov. 1994, transcript at 4 (cited in note 30).

182. Interview with Bethuel Maserumule and Osborne Galeni of the National Union of Metalworkers of South Africa, 10 Nov. 1994, transcript at 8 . I believe the frrst quoted comment is from Mr. Maserumule and the second from Mr. Galeni.

183. This point was made to me by Mr. Maserumule. Id. 


\section{B. The Speakers}

If conservative thinking tended to be modest in aspiration and apolitical in orientation, other Africans have long believed in their right to demand more of their government. Among Africans who held this conviction, there may have been two somewhat different orientations, which I seek to capture in the paradigms of "speakers" and "activists." The distinction I have in mind is between those who believed, or hoped, that the power of their words and their truth would convince those who heard them, and those who understood their political efforts as aimed at bringing coercive pressure to bear on their opponents. These two categories are not mutually exclusive, and it may be that many or most Africans who struggled against the state for the redress of their grievances thought in both of these ways. But the two orientations seem different enough to deserve separate treatment; moreover, the faith that some Africans seem to have had in the legal system needs to be explained as well as it can be. In sketching the following description of African "speakers," I offer an explanation very much based on inference, but an explanation which I think does help us to understand this startling attitude. In discussing the "speakers," we must first understand better the nature of their belief in the power of words to persuade and then see why the judicial system might have earned a measure of legitimacy as a forum in which those words could be spoken.

The desire to speak, I suspect, had two foundations. The first was the speakers' belief that they had rights. This belief is unremarkable in a citizen of the United States, but it might seem much less predictable in an African living under apartheid, a system largely designed to deprive Africans of rights. Yet rights consciousness-the sense that one has rights ${ }^{184}$ - has long played a role in African challenges to apartheid. ${ }^{185}$ The ANC's roots lay in an essentially liberal claim for "rights for Africans within the white state."186 Though developments after World War II certainly eroded this stance, ${ }^{187}$ I encountered the language of rights in the words of Lucas Kgatitsoe, whose rural people, the Magopa, had been the victims of a forced removal at the hands of the South African state.

Mr. Kgatitsoe, a powerful speaker, deployed the language of rights in his advocacy on behalf of his people. In a public statement he told the press that the Magopa would return to their land whether the government ap-

184. See Sarat, 11 Law $\&$ Soc'y Rev. at 449 (cited in note 113).

185. Jeremy Seekings emphasized to me the important, though not exclusive, role of rights discourse in Africans' challenges to white domination in South Africa.

186. Gail M. Gerhart, Black Power in South Africa: The Evolution of an Ideology 12 (1978). At 94 Gerhart emphasizes the "political and civil rights" content of the Freedom Charter.

187. Gerhart, id. at 16, maintains that "the history of postwar African political thought is one of a protracted process of tearing loose from liberalism as a world view." 
proved or not, because the land was their "birthright."188 Similarly, in a meeting with a government official, he asked the official to buy him an air ticket to Cape Town to meet the cabinet and argued that "this cabinet is the cabinet that rules my life, is the cabinet that rules South Africa. And I am a South African. So I have the right even if the apartheid policy says it ... denies me . . that right." 189

Mr. Kgatitsoe's use of these rights-based appeals must have been all the more effective, however, because he plainly believed that he did have rights. I asked him to explain this belief, and he told me: "I . . . believe that I have the right [in this case, to organize a union] because I'm born here in South Africa and I'm a South African." Despite the laws that denied him rights, "I still have the right as a bona fide of this country and God placed me in this country and I have all the rights just like anybody else. And that is just what I say and I believe that there is no other way that I can be ... true to myself."190 In part, this is a claim based on citizenship. It also seemed to be based on another political point - that whites had made these unjust laws without consulting blacks. ${ }^{191}$ But Mr. Kgatitsoe does not seem to be thinking solely in political terms. In addition, he seems to be describing the claiming of rights, or the struggle for them, as essential to his personal integrity. And he is certainly also speaking in religious terms, which he went on to elaborate in response to my inquiry. He invoked his Christian faith to say that "we are all created by God and we have the same rights anywhere and anyhow," rights that no one can take away. ${ }^{192}$

The second foundation of the desire to speak was the belief that when their story was told, Africans' rights would, or might, be honored. Often this confidence was surely tempered; as Thandi Orleyn put it to me, Africans approached the courts with hope rather than faith. Lucas Kgatitsoe, for example, was perhaps more of an activist, in my terminology, than a speaker; he was not optimistic about winning in court, and explained that the Magopa brought suit in part to win publicity and attention. He also said, however, that they acted in part because "we knew that . . . at the end,

188. Kgatitsoe interview, 3 Nov. 1994, transcript at 2 (cited in note 40).

189. Id. Mr. Kgatitsoe commented that "we did not agree on that one."

Mr. Kgatitsoe also made a somewhat rights-oriented claim, but a more deferential one, when he calmed another official-who had called Mr. Kgatitsoe a "kaffir" (an abusive term for "black") and threatened to break off negotiations-by telling him: "I believe that you are my father and ... as a father I do not believe ... that it would be right for you to tell me that you are going to ... just ... shut us out because there is no other father that I can go to. ... [I] as a father you are going to treat me that way then I don't know that it is right for a father to ... treat his son that way." Id. at 1 . Geoff Budlender, a veteran public interest lawyer in South Africa, told me that Africans repeatedly used this appeal to whites' duties as their "fathers" to good effect.

190. Id. at 3-4.

191. Id. at 4.

192. Id. 
justice shall be seen to be done"; "the hope was there."193 Other Africans, however, seem to have had greater confidence. One lawyer told me that one group of rural clients he represented often had more confidence that they would get justice through the courts than he did. A unionist told me that the union members she assisted in the Industrial Court did expect justice there; when they didn't get it, moreover, they did not accept her explanation that the true nature of the system was adverse to them but instead suspected that in their particular case justice had been denied because of bribery. And a community organizer who had worked with communities, including the Magopa, in removal cases, suggested that her clients might have felt that justice would prevail through them-a sentiment with a religious flavor-and that perhaps they felt that if they had their say in court the judge would be convinced.

Some part of the legitimacy of the courts in the eyes of speakers may have flowed directly from the speakers' own religious convictions, but to the extent that the speakers saw their words as potentially persuasive the legal system could also have earned legitimacy because it allowed those words to be spoken - by the litigants themselves, or by their lawyers. Not always, and not in every court: the pass courts operated in assembly-line fashion, and many people were probably poorly heard, or not at all, in the magistrates' courts as well. ${ }^{194}$ At least in the Supreme Court, however, litigants had the opportunity to tell their story. Africans' day-to-day experiences in dealing with white officials under apartheid were rarely pleasant; ${ }^{195}$ it may almost be true, as one law teacher said to me, that the Supreme Court was the only place in the country where blacks were treated with civility.

As we have already seen, Tom Tyler has found evidence that procedural justice is very important to judgments of legitimacy in the United States. I encountered repeated suggestions in South Africa that the opportunity to be heard was important there as well. Thus Don Nkadimeng, though he saw Africans as strongly critical of the courts, also commented that the sheer fact that they had an opportunity to be heard "to many people was sufficient to establish credibility on the part of the Supreme Court."196 That the Supreme Courts provided this opportunity may reflect the conscientiousness or even the sympathies of the judges; it may also reflect the greater public scrutiny these courts received; and it may also be attributable to the fact that clients in the Supreme Courts were more likely to be represented,

193. Id. at 5.

194. Jotham Zwane remembered hearing a magistrate say, from the bench, "Be quiet you kaffir!" Zwane interview, 8 Nov. 1994, tape 2 transcript at 18 (cited in note 178).

195. According to a 1985 Human Sciences Research Council report, "Africans in particular but perhaps other groups too, experience the ... actions of the officials as indicative of the inaccessibility, lack of sympathy, etc. of the authorities and of whites." South African Society 89 (cited in note 60).

196. Nkadimeng interview, 2 Nov. 1994, transcript at 9 (cited in note 139). 
and by the very group of lawyers--the advocates-from whose ranks the judges themselves were drawn. ${ }^{197}$ But, in any event, Africans' stories did get told in the Supreme Courts-however filtered the storytelling may have been through legal discourse-and for the people whom I have called "speakers" this opportunity may well have been an important source of legitimation.

\section{The Activists}

Just as it would be a mistake to characterize the South African legal system as having fairly and effectively protected Africans from crime, so it would be a mistake to say that this system strongly and consistently resisted the injustices of apartheid. Conservative Africans may have been willing to forgive a great deal in forming their judgments of the legal system's crimecontrol performance, and "speakers" may have been sustained by their belief in the power of the words they were able to utter in court. "Activists," however, men and women who were vividly conscious of the injustices pervading their lives, and who saw their task more as the mobilization of pressure against whites than as the transformation of whites' hearts, seem less likely to have exaggerated any virtues the legal system might have. Though it is impossible to be certain, I suspect that African "activists" have not been among those who have affirmed confidence in the country's legal system in polls over the years.

Nevertheless, it would also be a mistake to ignore those respects in which the courts, or at least some of those who judge or litigate in them, have limited the injuries done by apartheid, and it would likewise be a mistake to assume that activists have simply ignored this aspect of the South African legal system. I suggest, rather, that the modest achievements of the South African legal system on this score may have helped to legitimize the ideals of impartial adjudication and courageous protection of legal rights, even as radical observers of this system found much reason to say that those ideals were not being realized. Three factors, in particular, might have contributed to this result: the courts' surprisingly restrained handling of political trials, the respect earned by anti-apartheid lawyers themselves, and the guidance of political leaders.

\section{The Courts' Handling of Political Trials}

Let us consider the statistics on the rates of conviction in political trials-perhaps the cases with which activist victims of apartheid would be most concerned, and from which they might draw the most compelling evi-

197. Some of these points were made to me by Mr. Nkadimeng, id. at 9-10. 
dence for their own assessments of the courts. ${ }^{198}$ Government statistics offer us one picture of these results. Government statistics for 1 July 1992-30 June 1993 report convictions in 96 of the 123 prosecutions for crimes against state security (a conviction rate of $78 \%$ ), and in 8,378 (or $73 \%$ ) of the 11,442 prosecutions for crimes categorized as involving "law and order," at least some of which would probably have been "political" offenses. ${ }^{199}$ These statistics suggest that the courts are refusing to convict about a fourth of the people brought up on these serious charges. The conviction rates in nonpolitical cases appear to be quite comparable. ${ }^{200}$ This information might be taken to suggest at least that the courts act with some measure of scrupulousness even in political trials.

It appears, however, that in some political cases the rates of conviction are much lower. As compiled by the Human Rights Commission (HRC), an independent monitoring body with no fondness for the government, the numbers of those charged with political offenses in recent years who have actually been convicted are set out in table 5 . As this table reflects, the conviction rate in these political cases during the years 1990-93 has never been as high as $19 \%$. It might be thought that these remarkably low conviction rates are simply an expression of the winds of reform sweeping through South Africa by 1990 , but this does not appear to be the case. Earlier HRC data, though seemingly less complete, suggest that political trials generally did not end in conviction during the years from 1986 to 1989 either-and these years were the height of the state of emergency. 201

It is not clear how to explain this discrepancy. It may be that the Human Rights Commission's conviction rates are lower because it tracked cases from an earlier stage, while the government statistics address only those cases which are taken to the point of actual prosecution. It may also

198. The efforts of anti-apartheid lawyers were not confined to political trials. Other work went on in litigation challenging emergency powers, and this work ultimately was often, though not always, unsuccessful. Still other legal challenges, however, were brought in civil cases dealing with such issues as influx control and labor law, and in some of these fields antiapartheid lawyers won important victories that might also have attracted the attention of activist African observers.

199. Central Statistical Service, Crimes: Prosecutions and Convictions with Regard to Certain Offences Table 2 (Prosecutions and Convictions According to Class, Subclass and Offence-7 years and older) (CSS Report No. 00-11-01 (1992/93)). I am grateful to Nico Steytler for providing this material to me. Of the 8,378 convictions for "law and order" offenses, 7,150 are for crimes involving arms and ammunition; many or most of these offenses may have had no political content.

200. For crimes of "personal relations," evidently including most crimes of violence, the conviction rate was $74 \%$; for property crimes, the rate was $78 \%$. Id., Table 4 (Result of Prosecutions according to Class and Subclass).

201. The Human Rights Commission's figures for earlier years are less elaborate, and perhaps less complete, but still suggest conviction rates comparable to, though not as low as, those for 1990-93. In 1986, according to the Commission, there were 195 convictions out of 690 people accused (28.3\%); in 1987, 229 of $792(28.9 \%)$; in 1988, 255 of $574(44.4 \%)$; and in 1989, 493 of 3,183 (15.5\%). Human Rights Commission, Human Rights Update: Review of 1989, March 1990, at 8. 
TABLE 5

Political Trial Outcomes, 1990-1993

\begin{tabular}{|c|c|c|c|c|c|}
\hline & $\begin{array}{l}\text { Total No. } \\
\text { Accused }\end{array}$ & $\begin{array}{c}\text { Convictions \& } \\
\text { Admissions } \\
\text { of Guilt }\end{array}$ & $\begin{array}{l}\text { Acquittals \& } \\
\text { Cases Discharged } \\
\text { or "Struck } \\
\text { from the Roll" }\end{array}$ & $\begin{array}{c}\text { Cases } \\
\text { Withdrawn }\end{array}$ & $\begin{array}{l}\text { Convictions as } \\
\% \text { of Total } \\
\text { No. Accused }\end{array}$ \\
\hline $\begin{array}{l}1990 \\
1991 \\
1992 \\
1993\end{array}$ & $\begin{array}{l}3,894 \\
3,246 \\
4,298 \\
1,747\end{array}$ & $\begin{array}{l}710 \\
478 \\
708 \\
251\end{array}$ & $\begin{array}{l}657 \\
418 \\
184 \\
305\end{array}$ & $\begin{array}{l}2,527 \\
2,145 \\
3,379 \\
1,145\end{array}$ & $\begin{array}{l}18.2^{\mathrm{a}} \\
14.7^{\mathrm{b}} \\
16.5^{\mathrm{c}} \\
14.4^{\mathrm{d}}\end{array}$ \\
\hline
\end{tabular}

' Hansson, 1992 S. Afr. Crim. Just. at 319 (cited in note 117), citing Human Rights Commission, 3 (11) Hum. Rts. Rev., Dec. 1990, at 4.

b Id. citing Human Rights Commission, 4 (12) Hum. Rts. Update, Dec. 1991, at 6. In 1991, 190 persons were also granted indemnity.

c Human Rights Commission, 5 (12) Hum. Rts. Update, Dec. 1992, at 12. These figures are for 1992 through 25 December and were subject to revision as late-arriving information came in. In addition, 19 people were granted indemnity and 8 absconded.

d Human Rights Commission, Monthly Repression Rep.-Dec. 1993 at 4. In addition, 1 person was granted indemnity and 21 absconded. Another Human Rights Commission publication gives a somewhat higher number for convictions (305), but I suspect this is an accidental transposition of the figure for acquittals. Human Rights Commission, Hum. Rts. Rev.: South Africa 1993 at 7.

be that the Human Rights Commission's classification of cases as political intersects only quite approximately with the most "political" categories of the government's statistics. But it seems clear, whatever the resolution of these issues, that a very substantial number of people who at one point faced the danger of prosecution for acts with political overtones have been able to escape conviction. It may be, as well, that the cases which acquired the most visibility as "political" cases-and so might have been the most likely to be picked up by the Human Rights Commission's statistics-were notably unlikely to result in convictions. ${ }^{202}$

As a system of political repression, in short, prosecutions in South African political trials were certainly not irresistible and may have worked decidedly poorly. Undoubtedly many of the accused in these trials were subjected to great suffering at the hands of the police, and to prolonged interruptions of their lives, but when they finally came to court, they could often hope to escape conviction. If the reason that conviction was not inevitable, and perhaps unlikely, was that the courts insisted on fair procedures

202. This inference is supported by a comment of Nomazizi Mtshotshosa. She told me that she is a board member of the South African Legal Defense and Education Fund, which then funded defenses in political cases, and that the conviction rate in cases which they were funding was only about 4\%. Mtshotshosa interview, 7 Nov. 1994, transcript at 13 (cited in note 30 ). Presumably the cases that attract such funding support are, again, among the most visible "political" cases.

Certain "political" prosecutions, however, seem to have been very likely to produce convictions-notably, as various data suggest, those for treason and terrorism. 
and sufficient proof, then the accused in these trials-and the members of the public who followed these events - could have come to accord a measure of recognition to these benign aspects of the courts. Since many of these trials appear to have taken place in the magistrates' courts rather than the Supreme Courts, ${ }^{203}$ moreover, even these lower courts might have garnered a modicum of respect as a result of these trials. (Some individual judges on the Supreme Courts, however, would deservedly have stood out for their vigilance in seeking to salvage as much justice from South African law as possible.) As evidence of the problems of the people's courts accumulated, even activist Africans might have seen in that grim experience further reason to value the degree of evenhandedness the formal courts sometimes attained.

Whether those who experienced or followed these trials attributed their results to any qualities of the courts, however, is far from clear. While I believe that some part of the explanation of these low conviction rates must be found (as one South African lawyer observed to me) in the courts' refusal to countenance intolerably low standards of proof of guilt, other factors were surely at work as well. The state may have been unwilling to expose some of its evidence to public view, and may have felt that it had already exacted a form of punishment in the course of pretrial detention. Police investigations may well have been slipshod and the evidence of guilt scanty. Witnesses the state might have called to testify against the accused, moreover, may have refused to testify, either out of political commitment or out of fear of later reprisal. Even to the extent that the judges were responsible for the results, finally, observers who were conscious of other grounds for challenging these same judges may simply have found these events unpersuasive as evidence for any claim of the judges' virtue. One black lawyer, for example, attributed magistrates' decisions not to convict in cases where the evidence was extremely weak not to honesty but to the desire to avoid embarrassment. ${ }^{204}$ But activists had other reasons as well for recognizing the judicial system's potential.

\section{Legitimation by Association with Anti-Apartheid Lawyers}

Albie Sachs has commented: "It might even be argued that the more unfavourably Africans felt towards the laws [of South Africa], the more

203. I base this inference on a review of the data on political trials compiled by the Human Rights Commission in late 1989; only a limited number of the many trials mentioned in the Updates covering this period are noted as taking place in the Supreme Courts. See Human Rights Commission, 2 (4) Hum. Rts. Update: Sept-Oct 1989, Nov. 1989; id., 2 (5) Hum. Rts. Update: Nov-Dec 1989, Jan. 1990.

204. Tom Lediga, in Tlakula \& Lediga interview, 7 Nov. 1994, transcript at 16 (cited in note 29). 
well-disposed they were towards the lawyers."205 Whether or not that is literally true, it does seem likely that anti-apartheid lawyers have won the respect of many of those they represented. Among the people accompanying Nelson Mandela to Oslo for the Nobel Peace Prize ceremonies was a white lawyer, George Bizos, who had been one of Mandela's lawyers when he was sentenced to life imprisonment 30 years earlier. ${ }^{206}$ Some months earlier, Mandela had attended the dinner honoring the retiring director of a leading South African public interest law group, the Legal Resources Centre, and was photographed, grinning, with the outgoing director and his successor. ${ }^{207}$ After a group of prominent United Democratic Front activists were freed by South Africa's highest court in 1989, their lawyers were applauded with the cheer "Viva democratic lawyers viva!" I am sure that anti-apartheid lawyers have also won respect for the day-to-day work they do on behalf of a wide range of individual clients facing a host of problems, particularly as the advice centre movement has made it possible for a much wider range of Africans to obtain legal help. ${ }^{208}$

These lawyers have been both prominent and obscure. No doubt they have held views of South African law and of law in general that have ranged from tempered faith to utter cynicism. My sense, however, is that many of these lawyers took very seriously indeed what they saw as the highest aspirations of the legal system. Some of them, moreover, have been people who had manifestly gained the professional respect of their peers in that system. Those who admired these lawyers may have found some ground for admiring what these lawyers valued as well, and for admiring a profession in which people could oppose injustice and fight against it. ${ }^{209}$ Perhaps they

205. Sachs, Justice in South Africa at 202 (cited in note 159).

206. Bill Keller, "2 South Africans Peer into Future," N.Y. Times, 10 Dec. 1993, at A7.

207. Arthur Chaskalson retired as national director of the Legal Resources Centre in September 1993 and was succeeded by Geoff Budlender. Chaskalson, Mandela, and Budlender stand side by side in a photograph published in the LRC News (Winter-Spring 1993/94). Chaskalson has since been appointed as the President of South Africa's new Constitutional Court.

208. One leader of a community represented by an anti-apartheid lawyer described that lawyer as being "as close as our underpants"-a recognition not of impropriety but of the lawyer's intense engagement with the people with whom he worked.

209. One veteran of a long political trial told me that many people imprisoned for political offenses studied law on Robben Island. He himself, now free, is in law school. (A lawyer pointed out to me, though, that part of the reason for the Robben Islanders' choice of fields may have been that for various reasons they could not get permission to study certain other subjects.) As noted earlier, see text at note 171 supra, many who worked in advice centres as paralegals (again, probably in part because they could not work elsewhere) were also political activists.

Quite aside from the veterans of political trials, a considerable number of black South Africans have chosen in the past two decades to become lawyers. This choice might be taken as a recognition of the comparative openness of law as compared with other South African institutions. But black lawyers often have sharply negative views of the system within which they work, and most may well have seen their choice to practice law as, in the words of Pansy Tlakula, a choice made "because there was nothing else." Tlakula \& Lediga interview, 7 Nov. 1994, transcript at 11 (cited in note 29). 
also were moved by the contact with white lawyers who actually opposed apartheid ${ }^{210}$ and with black lawyers who had learned to manipulate the rulers' system. ${ }^{211}$ Even if they also viewed their lawyers as not being part of the existing legal system-as I was told more than once ${ }^{212}$ — clients might have found reason to admire the values that a legal system could embody in a post-apartheid nation. ${ }^{213}$

\section{Legitimation through the Efforts of African Leaders}

I do not suggest that activist Africans faced with indications of judges' care and lawyers' courage could only conclude that the South African legal system, or even some of its asserted ideals, had earned some degree of legitimacy. For those who did not draw such conclusions spontaneously, however, there remains a significant possibility-that they might come to accept such views to the extent that African leaders endorse them.

The values of African leaders do not control the views of their fellow Africans, but like leaders everywhere these men and women certainly can affect their supporters' views. As we have already seen, moreover, many Africans-perhaps including many activists-are not well educated and do not have detailed information about many of the issues and institutions of South African life. ${ }^{214}$ African leaders are likely to have considerable ability to sway their followers' opinions on those issues on which the man or

210. Jotham Zwane, who struggled for years against the pass law system and against apartheid in general, finally was able to resolve his pass problems with the help of Geoff Budlender of the Legal Resources Centre. Mr. Zwane said of his lawyer that he was "powerful on his points," and that he was "against the apartheid. That's why ... he was powerful. ... Geoff ... had a green light ... to say where to go with the apartheid." Interview, 8 Nov. 1994, tape 2 transcript at 16 (cired in note 178).

211. For example, an anonymous reviewer of this article emphasized the respect blacks had for the legal work of Nelson Mandela and Oliver Tambo in the 1950s. Similarly, Yvonne Mokgoro-now the first African woman to serve on South Africa's Constitutional Courtbecame a lawyer in part as a result of the inspiration of Robert Sobukwe, a lawyer who was also a founder of the Pan Africanist Congress. After Ms. Mokgoro was arrested in a pass law raid, Sobukwe got the charge against her dismissed. "As they were walking away from the court, Mokgoro remarked to him that more men needed to be trained as lawyers and he turned to her saying 'Don't let me hear you say that again. Law might seem like a maledominated profession but women can do it and we should start with you." "Alice Coezzee, "The 'People's Judge," 8 (7) Democtacy in Action, 15 Dec. 1994, at 7.

212. In the words of Tom Lediga, "They would even call you 'comrade." "Tlakula \& Lediga interview, 7 Nov. 1994, transcript at 17 (cited in note 29).

213. Finally, to the extent that these lawyers also succeeded in persuading or enabling some South African judges to render decisions protecting the victims of apartheid, they may have contributed to the degree of legitimation that the courts were earning through their handling of such litigation. Judge Richard Goldstone, who as chair of the Goldstone Commission led important and sometimes dramatic inquiries into the sources of political violence in South Africa, told me that one reason his commission-headed as it was by a sitting South African judge-was able to function was that the victories won by anti-apartheid lawyers had conferred legitimacy on the judiciary. Personal communication, 16 April 1993.

214. See text and note at note 114 supra. 
woman on the street is not well informed. Thus Mark Orkin notes "the established finding from political sociology that voters tend to follow party orientations on policy issues. The tendency is even stronger on issues about which they are not very knowledgeable."215 If, therefore, an African elite finds some merit in the legal process in South Africa, they may be able to communicate that view persuasively to others in their communities-as long as they retain the support of their erstwhile followers.

This phenomenon may in fact be at work. There is some evidence suggesting that African elites are modestly more confident in the legal system than are other, less privileged African men and women (see appendix 2). Admittedly, this does not seem to be the case for African lawyers, who might be expected to be particularly influential with their clients on the question of the virtues of the legal system. But there is also evidence that members of one especially influential African elite-the political leaders engaged in the shaping of a new constitution-entertain a measure of such confidence. I have already mentioned the stance of Nelson Mandela, who combines stern criticism of this system with participation in it and seemingly with respect for its better features. As we will see in a moment, moreover, during the negotiations that ended apartheid, the ANC as a whole embraced a process whose results bespeak at least a tolerance for legalism and a measure of confidence by the ANC in its ability to achieve power in such a framework. Because Nelson Mandela and the ANC at this time enjoy preeminent popularity among Africans, we can infer that they will tend to influence their many supporters to share these views-although we must also recognize that outside the ANC, and even within it, more impatient voices also enjoy an attentive audience. ${ }^{216}$

If anti-apartheid lawyering has played a role in the development of this stance among ANC negotiators, it did not engender unqualified faith. Indeed, the ANC's confidence in the legal system not long ago may have been considerably more attenuated, to say the least, than it is today; Albie Sachs has commented that "South Africa must be the only country in the world in which sections of the oppressed actually constituted an anti-Bill of

215. Orkin, "Politics" at 87 (cited in note 60). Orkin also maintains that Africans' "fundamental policy orientations to economic pressures, violence, and other strategies for change are actually largely shaped by party-political allegiance" (at 81 ). He notes, however, "the considerable extent to which [African] respondents have not felt obliged to follow their leaders" on the sanctions issue, whether their leaders favored sanctions or opposed them (at 90-91; emphasis in original). See also Schlemmer, 3 (4) Indicator SA at 5 (cited in note 104).

216. One of these voices is that of Winnie Mandela, who capitalized on her popular following to regain "her position as president of the Women's League of the African National Congress," a year after she lost this post following her notorious conviction "for her involvement in the 1988 kidnapping of four young [African] men." Kenneth B. Noble, "Winnie Mandela Regains Post in Women's Group," N.Y. Times, 9 Dec. 1993, at A6. Her saga continues. Appointed as a deputy minister in South Africa's first post-apartheid cabinet, she has recently been fired from that post. It is hard to believe that her dismissal will be the end of the story. 
Rights committee."217 But this confidence seems to have grown, perhaps in part as a result of the ANC's growing connections with anti-apartheid lawyers in South Africa and with their supporters abroad. It may be, in fact, that anti-apartheid lawyers, who won their own legitimacy in the eyes of the system's victims by waging legal battles against it, have played a direct and personal role in legitimizing the framework of legalism among the negotiators for the ANC. A number of lawyers themselves played central roles for the ANC in the negotiations that led to the interim constitution now in place, ${ }^{218}$ and the trust they evidently enjoy can only have enhanced the influence of their perspectives on law. ${ }^{219}$

The suggestion that African activists might accord a measure of legitimacy to the ideals of the legal system remains speculative. But the reasoning I have suggested Africans might engage in has, I believe, a plausible ring to it. Africans, confronted with great injustice, would have drawn conclusions from that. At the same time, confronted with great dangers from crime, they had good reason to accord some respect to any institution that helped protect them, and the criminal justice system has been such an institution. In addition, witnessing the occasional achievements of the South African legal system, they had reason to draw conclusions from this evidence as well; we can infer-though we do not really know-that they in fact drew, or will come to draw, these conclusions. Moreover, this suggestion of activist legitimation helps us to understand aspects of the actual South African scene,

217. Albie Sachs, Protecting Human Rights in a New South Africa 6 (1990).

218. Among the lawyers or legally trained activists who helped shape the ANC's positions or negotiate on its behalf (besides Nelson Mandela himself) were Kader Asmal, a legal scholar long in exile but by then returned to the University of the Western Cape (and now a cabinet minister); George Bizos, a leading anti-apartheid advocate; Arthur Chaskalson, another leading public interest lawyer (now President of the Constitutional Court); Nicholas Haysom, a scholar and practitioner involved in a wide range of anti-apartheid litigation (now counsel to President Mandela): Brigitte Mabandla, trained as a lawyer while in exile (now Deputy Minister of Culture); Penuel Meduna, a lawyer who went into exile during the years of apartheid (now Deputy Minister of the Interior); Abdullah Omar, a lawyer who had represented Nelson Mandela and who only a few years earlier had been a victim of emergency powers himself (see Omar v. Minister of Law and Order, 1987 (3) SA 859 (A)) (now Minister of Justice); Matthew Phosa, another lawyer who went into exile (now Premier of the Eastern Cape province); Cyril Ramaphosa, a prominent union leader with law training (now the Chair of the Constitutional Assembly); Albie Sachs, a lawyer and scholar who suffered not only detention but also mutilation at the hands of the apartheid regime (now a judge of the Constitutional Court); and Joe Slovo, a lawyer and long-time leader of the South African Communist Party (Minister of Housing in the new government until his recent death). Even this long list leaves out other distinguished lawyers who contributed to this process.

219. It is worth mentioning that although the ANC took a more moderate position in the negotiations than one of its rivals, the Pan Africanist Congress, the latter group also has ties to the culture of anti-apartheid lawyering. One of its senior officials, until late in 1992, was Dikgang Moseneke, an African advocate who played an important part in the drafting of the interim constitution and in the Independent Electoral Commission that oversaw the April 1994 elections. In addition, distinguished anti-apartheid legal scholars contributed to the negotiations on behalf of the liberal Democratic Party and in other roles. 
such as the course of constitutional negotiations, and the comments of Nelson Mandela and Tokyo Sexwale cited earlier in this essay. ${ }^{220}$

A recent, remarkable example offers a further tantalizing hint that indeed some African observers, some of the time, have found something to respect in the administration of justice in South Africa. This example comes from the trial of the alleged killers of Amy Biehl, a white American woman who during her time in South Africa had reportedly worked closely with the ANC, but was brutally killed by black youths who did not know her but saw her as a "settler." As this trial progressed, supporters of the ANC and of its rival, the Pan Africanist Congress, "jogged in competing toyi-toyis, in solidarity with their comrades inside the court. For the ANC supporters, it must have felt strange to support proceedings in a court forming part of a judicial system long seen to mete out white man's justice." As for the PAC supporters, "it's clear few expect justice from a court commanded by 'settlers.' "221 The ANC supporters, mobilized in support of the South African legal system, apparently have taken what might be called an activist stance in favor of the system's partial legitimacy.

At the same time, it may well be that those who were influenced by this activist perspective on legitimation never expressed that acceptance in affirmations of confidence in the South African legal system as it stood under apartheid, and so are not part of the explanation for the expressions of confidence in the legal system in the opinion polls on which this article focused earlier. Instead, what is being legitimized here may be the ideal of the rule of law rather than the very flawed approximation of that ideal that has held sway in South Africa until now. I do not at all suggest that Africans draw their views on law as an institution solely from their observation of the functioning of the institutions fashioned by the white rulers of South Africa, for Africans have their own traditions of law to consult as well. But the evidence that the legal system under apartheid could generate results that did not serve apartheid's interests, as well as the evidence that men and women devoted to the law could also be profoundly committed to the struggle against apartheid, could well have played a part in Africans' judgments about law's potential, and so in the legitimation not of the existing legal system but of the value of the rule of law in a future South Africa.

\section{The Impact of Anti-Apartheid Lawyering on Africans' Legitimation of the Legal System}

Although the three paradigms of African thought that I have just sketched are quite different, I believe that anti-apartheid lawyering may

220. See text and notes at notes 35-39 supra.

221. Gaye Davis, "Warring Camps in the Biehl Trial Corridors," Weekly Mail \& Guardian, 26 Nov.-2 Dec. 1993, at 9. 
have contributed to the process of legitimation within each of these perspectives. The nature of that contribution, however, may well have varied from paradigm to paradigm. Here let us recapitulate what we have learned as it sheds light on the particular impact of anti-apartheid lawyering.

The effect of anti-apartheid lawyering on conservative Africans seems likely to have been the most ambiguous. For people primarily concerned with issues of order and crime control, anti-apartheid lawyers' work may have attracted attention only when these lawyers defended people accused of crimes committed for political reasons. In defending such people, antiapartheid lawyers may have actually frustrated some conservative Africans' desire for effective crime control-or, by playing their part in the process of criminal adjudication, they may have reinforced these observers' confidence in the courts.

But not all conservatives were exclusively focused on crime. Many, perhaps most, also were concerned, albeit in a cautious and restrained way, with improving their lot under apartheid, and on this score the legitimizing impact of anti-apartheid lawyering may have been more clear-cut. By helping to establish the array of advice centres around the country and by providing legal help 'to a great many black South Africans through them, antiapartheid lawyers (and paralegals) may well have enhanced popular, conservative views of the legal system. More generally, lawyers who were able to make the system work on behalf of black people may have helped conservative Africans, disposed as they were to moderate assessments of the system under which they lived, to see virtues in the legal system. Finally, to whatever extent the heritage of racial subordination affected the thinking of some conservatives, it seems possible that contact with those antiapartheid lawyers who were white contributed to their willingness to see virtue in white institutions.

For the speakers and the activists, the impact of anti-apartheid lawyering seems likely to have been more unambiguously legitimizing. Such lawyers enabled the speakers to tell their stories or told them on their clients' behalf. 222 They helped win victories, on behalf of speakers and activists (and conservatives). The lawyers who won these victories or fought against the many defeats that also took place deserved the trust they sometimes, perhaps commonly, won from their clients as a result. And among the closest observers of their work would have been the African political leadership,

222. Certainly lawyers who were poor storytellers or who made their clients feel that their own stories were being unjustifiably silenced would not have won applause. My sense, however, is that South African clients, even activist ones, tended to take lawyers' advice very seriously; for example, I was told more than once that accused activists who had intended to refuse to participate in their trials had been persuaded by their lawyers not to take that course. E.g., Mtshotshosa interview, 7 Nov. 1994, transcript at 12 (cited in note 30). I suspect that clients also often recognized that even relatively bleak outcomes were better than what might have ensued without a lawyer's assistance. 
many of whom were themselves clients and all of whom were likely to be affected by the outcomes of these lawyers' efforts. The upshot is that it seems likely that the efforts of anti-apartheid lawyers have in fact played a part in winning the South African legal system, or at least the ideals toward which the legal system at its best aspired, a measure of respect among African speakers and activists.

In short, anti-apartheid lawyering probably did contribute to the legitimation of the South African legal system or, more precisely, to the measure of legitimation that that system and its ideals appear to have enjoyed.

\section{WAS THE PARTIAL LEGITIMATION OF THE LEGAL SYSTEM DESIRABLE?}

If the South African legal system enjoyed a measure of legitimacy among Africans, and if, in particular, legal ideals enjoyed a measure of legitimacy among African activists and political leaders, then we would expect to see in the design of the new South Africa evidence that Africans, or at least their leaders, see law as a central protection against injustice, even the injustice that they themselves might do. This is in fact what we do see when we look at the elaborate interim constitution that has now been adopted to govern South Africa. The evidence is not unambiguous, for the transitional agreements which the ANC endorsed are the product of compromise rather than a simple expression of the ANC's preferences. ${ }^{223}$ Moreover, they are the product of a process in which lawyers-whose disposition toward legal arrangements may not have been shared by those they represented-played a major role. In addition, some important elements of the compromise entail significant modifications of the power of the current South African judiciary. But it is hard to read this constitution without inferring that those who agreed on it, including the ANC, must have had a sense that the existing judiciary can be drawn on, or guided, so as to play a useful part in a new South Africa.

To see the working of legal ideals more precisely, let us look closely at the interim constitution. Even physically this document bespeaks its lawyerly roots-its more than 220 pages (including both English and Afrikaans texts), over 250 sections and countless subsections attest to the close attention to legal detail that informed its drafting. 224 The interim constitution continues the present judiciary in place, ${ }^{225}$ a step that might be taken to

223. Howard Venable emphasized this point to me.

224. Constitution of the Republic of South Africa, 1993 (Act No. 200 of 1993) ("1993 Constitution"). For a more detailed analysis of this constitution, see Stephen Ellmann, "The New South African Constitution and Ethnic Division," 26 Colum. Hum. Rts. L. Rev. 5 (1994).

225. 1993 Constitution $\S 241$. 
reflect a modicum of faith in the legal system-except that the present civil service is also continued in place, ${ }^{226}$ and it may be widely reviled by South African blacks.

Perhaps more significantly, the principal changes made in the judicial system are changes that enhance the role of the courts as guarantors of liberty. First, to provide greater assurance of the judges' impartiality, the interim constitution changes the system of appointments of high court judges, whose selection had been in the hands of the government of the day. ${ }^{227}$ Second, the interim constitution gives South Africa, for the first time, a judicially enforceable set of constitutional liberties and thereby abrogates the longstanding tradition of Parliamentary supremacy. ${ }^{228}$ Third, the interim constitution credtes a new Constitutional Court to take primary responsibility for construing the Constitution; this step does suggest a lack of complete faith in the existing judiciary, but it hardly reflects a lack of faith in adjudication. ${ }^{229}$ Fourth, this constitution gives the Constitutional Court a remarkable role in the process of adopting the new constitution which will govern South Africa when the interim constitution is superseded. The Constiturional Court's role in this respect is to determine whether the constitutional text that the new Parliament develops in its capacity as a Constitutional Assembly is in compliance with a set of 34 constitutional principles included in the interim constitution. Without the Constitutional Court's approval, a proposed constitution will not be able to take effect. ${ }^{230}$ The faith this proposal puts in the fidelity of judges suggests that the negotiators of the interim constitution were decidedly hopeful about the efficacy and reality of the rule of law. ${ }^{231}$

\section{Id. $\$ 236$.}

227. Until the new constitution, appointments to the Supreme Courts had been made by the government in office, albeit subject to the constraint that such appointments as a matter of practice were almost always made from the ranks of the elite of the private bar, the "senior counsel." Though some of these appointments were painfully political, it is a fact that the National Party government appointed a number of judges who proved to be decidedly unsympathetic interpreters of apartheid laws. See Ellmann, Time of Trouble 227-29 (cited in note 2).

Under $\S 104(1)$ of the 1993 Constitution, Supreme Court judges will now be "appointed by the President acting on the advice of the Judicial Service Commission." The members of this commission, in turn, include presidential appointees but also individuals designated by the legal profession, by the deans of the nation's law faculties, and by the upper house of the national legislature, as well as three sitting judges. Id. $\$ 105$.

228. Id. \$§ 7-35.

229. Id. \$98. The system of appointments to this Court was a matter of great controversy in the final stages of constitutional negotiations. The system on which the government and the ANC had agreed would have placed these appointments largely under political, and in particular presidential, control; as a result of opposition from the Democratic Party (and perhaps from others), the system ultimately agreed on gives the sitting Chief Justice and the Judicial Service Commission, among others, some capacity to constrain the president's selections. Id. § 99 .

230. Id. $\$ \S 71,74$.

231. For another striking indication of the new leaders' adoption of the old legal system, consider the example of Abdullah Omar. Omar, a former political prisoner (see note 218 
The heritage of anti-apartheid lawyering may also affect the extent to which this constitution is honored. It is of course true that this elaborate legal apparatus will come to naught if the people of the country show no disposition to abide by it. South Africa faces real risks of just such a collapse into disorder, civil war, or dictatorship. But these grim possibilities do not make the constitution irrelevant; rather, they confirm the importance of the nurturance of a political culture that values adherence to the constitution. ${ }^{232}$ In the building of that culture, the efforts of anti-apartheid lawyers and the decisions of those judges who found their arguments persuasive may offer confirmation of the value of shaping a legal order that is not simply a tool of the rulers of the day. This history may also help to certify the bona fides of those public interest lawyers who are already embarked on refocusing their anti-apartheid lawyering to the preservation of rights under a democratically elected government. ${ }^{233}$ The legal challenges to apartheid may have helped to build a post-apartheid legal culture already in South Africa's former colony, the new nation of Namibia; ${ }^{234}$ we can hope that it will have that effect in South Africa as well.

All these events might be just as I have described or anticipated them, and yet it might be answered that the impact of the legitimation of the South African legal system was negative rather than positive. This answer might recast the old fear that anti-apartheid lawyering directly legitimized the system of apartheid into a concern that the more limited legitimation of the legal system and of the ideal of the rule of law had enabled the South African government to preserve white privileges under the new constitution. It is true that the interim constitution preserves a considerable mea-

supra), is now South Africa's Minister of Justice. In 1990, he commented that when antiapartheid lawyers go to court "[i]t is not a question of using South African laws. It is a question of defending people against the laws. ... But you must go to court to fight injustice even though the laws are weighted against you." "What Does Mandela Want?" Hum. Rts., Fall/ Winter 1990, at 31, 46 ("Interview with Abdullah Omar by Vicki Quade"). Late in 1994, he told a forum that the "South African court system did not require a major review although representation needed to be addressed." "South African Court System Does Not Require Major Review," This Week in South Africa: News Highlights from the South African Media (S. Afr. Consulate Gen., New York, N.Y.), 8-14 Nov. 1994, at 4. (The quoted words are from This Week in South Africa and not, directly, from Minister Omar.)

232. See Davis, 18 Soc. Just. at 70, 78 (cited in note 92 ).

233. See Arthur Chaskalson, "The LRC in the Future," in Legal Resources Trust/Legal Resources Centre, Report for the Year Ended 31 March 1993 at 10, 12-14.

234. David Smuts, the founder of Namibia's Legal Assistance Centre, a public interest law group that began operations before independence and has continued them since, has said that he thinks that his Centre's "focussing on those kinds of [human rights] issues at that time [before independence], and empowering people in a way to actually understand what was going on in human rights cases, and to really get them informed and to try to provide redress" was "a very important achievement for the Centre, and in basically helping further the whole idea of the creation of a human rights culture." Interview with David Smuts by Jonathan Klaaren, May 1991, at 49. For the suggestion that the new Namibian constitution may, however, rely too much on judicial protection of rights against the state, see Nico Steytler, "The Judicialization of Namibian Politics," 9 S. Afr. J. Hum. Rts. 477 (1993). 
sure of white privilege, though it is also true that it enables the new government to embark on a considerable measure of reform and redistribution.235 I doubt, however, that the source of these results is primarily the negotiators' acceptance of legal values. Though we should not ignore the impact of intellectual perspectives on practical results, we are likely to be on sounder ground if we understand the outcome of South Africa's negotiations in this regard as first and foremost the outcome of a political struggle.

Let me take just one example to illustrate this point. The right to property, a matter of great concern to whites, receives considerable protection in the new constitution. Though there are constitutions which meaningfully protect human rights but omit explicit protection of property, and some South Africans may have looked to such documents as models, ${ }^{236}$ it may be that the negotiators' embrace of "rights talk" tended to push them to talk about property rights as well as other rights. But it is very hard to believe that South African whites, for whom economic privilege is likely to be their principal remaining power in a new South Africa, would have foregone protection of their property rights if rights talk had somehow been forgotten.

Finally, the legitimation of the idea of the rule of law might be attacked not on the ground that it insulated particular rights or claims but on the ground that reliance on formal rules and judicially protected rights ultimately disserves the goals of human liberty and community. This challenge is akin to some "critical" attacks on rights in the United States. Some Critical Race scholars here have responded by arguing that the ideology of rights, despite its underlying problems, has in fact promoted the liberty of oppressed groups in this country. ${ }^{237}$ South African experience similarly reminds us that a critique of rights talk is only plausible in a country that has actually succeeded in protecting some rights. South Africans, black and white but especially black, have suffered greatly for their country's lack of an apparatus of entrenched human rights protected by independent courts, as imperfect as any such apparatus will always be. To the extent that antiapartheid lawyering has contributed to teaching those who are shaping the new South Africa the value of such an apparatus, I believe it has served South Africa well.

235. See Ellmann, 26 Colum. Hum. Rts. L. Rev. at 34-40 (cited in note 224).

236. See Matthew Chaskalson, "The Problem with Property: Thoughts on the Constitutional Protection of Property in the United States and the Commonwealth," 9 S. Afr. J. Hum. Rts. 388, 408-11 (1993).

237. See Patricia J. Williams, The Alchemy of Race and Rights: Diary of a Law Professor 146-65 (1991); Kimberle Williams Crenshaw, "Race, Reform and Retrenchment: Transformation and Legitimation in Antidiscrimination Law," 101 Harv. L. Rev. 1331, 1356-69, 1381-87 (1988); Richard Delgado, "The Ethereal Scholar: Does Critical Legal Studies Have What Minorities Want?" 22 Harv. C.R.-C.L. L. Rev. 301, 303-12 (1987). 


\section{APPENDIX 1}

Coloured, Asian, and White Confidence in the Legal System, 1993 (Percentages)

\begin{tabular}{lccc}
\hline & Coloureds & Asians & Whites \\
\hline A great deal & 10.7 & 6.8 & 20.5 \\
Quite a lot & 26.5 & 28.3 & 31.6 \\
Not very much & 45.8 & 49.2 & 28.8 \\
None at all & 9.3 & 10.9 & 9.6 \\
Do not know & 7.7 & 4.8 & $9.4^{\mathrm{a}}$
\end{tabular}

SOURCE: "Markinor 1993 Statistics" at 20, Table 7/3 (Aug. 1993) (Coloureds and Asians); at 19, Table 10/3 (June 1993) (whites) (cited in note 57).

ancludes refusals to answer.

\section{APPENDIX 2}

\section{African Confidence in the Legal System, Education, and Income}

The data on education, income, and confidence in the legal system suggest some patterns. In both 1990 and 1993, urban Africans who were better off were relatively more likely to express confidence in the legal system than most of their lower-income counterparts. In addition, in 1990 and 1993 - but not in 1981 - the least and most educated urban Africans were more likely to express confidence in the legal system than those with intermediate levels of education. The impact of education seems to be more ambiguous than the impact of higher income, perhaps because of a tendency among some people with higher education to be more, rather than less, discontented with their lot. In any event, it does appear from these surveys (though the data are hardly conclusive) that the African urban elite includes a substantial number of people who are disposed by income and/or by education to be modestly more confident in the legal system than are their less privileged fellow citizens. The relevant data, drawn from "Markinor 1981 Statistics" at 46 (cited in note 55); "Markinor 1990 Statistics" at 171 (cited in note 56); and "Markinor 1993 Statistics" at 20 (cited in note 57), are shown in the following tabulations: 
A. Mean Levels of Confidence in the Legal System, by Education

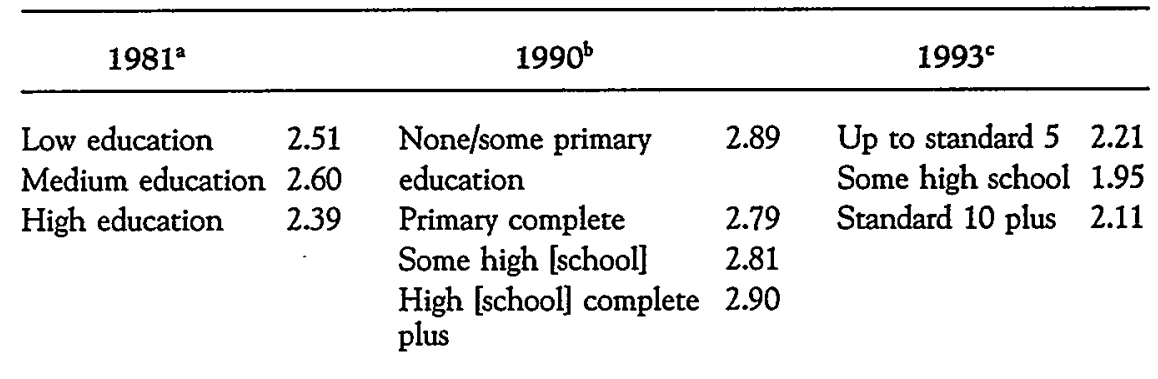

a Only the gap between those with low and medium education is within the poll's standard errors.

b None of the gaps between these subgroups exceeds the poll's standard errors.

c The gaps between the middle group and each of the others exceed the poll's standard errors.

B. Mean Levels of Confidence in the Legal System, by Income ${ }^{a}$

\begin{tabular}{llll}
\hline \multicolumn{3}{c}{$1990^{\mathrm{b}}$} & \multicolumn{1}{c}{$1993^{\mathrm{c}}$} \\
\hline R 699 [699 rands] or less 2.74 & R 699 or less & 2.11 \\
R 700-1,199 & 2.83 & R 700-999 & 2.01 \\
R 1,200 plus & 2.95 & R 1,000-1,999 & 2.02 \\
& & R 2,000-2,499 & 2.18 \\
& & R 2,500 plus & 2.18 \\
\end{tabular}

\footnotetext{
a I do not have data broken down by income for 1981 .

b Only the gap between the highest and lowest groups exceeds the poll's standard errors.

c The gaps between the two highest groups and the next two groups exceed the poll's standard errors.
}

Among rural Africans, no such pattern exists-at least in the 1990 data which I have. All groups' confidence in the legal system is quite similar. Better-educated and better-off rural Africans, however, express less confidence in the police than do those with less education or lower incomes, and these gaps exceed the poll's standard errors. There are some hints that advantages of education and income tend to produce lower confidence in Parliament as well, though the figures here are hardly clear-cut. "Markinor 1990 Statistics" at 163, 166-67 (cited in note 56). 


\section{AUTHOR'S ACKNOWLEDGMENTS}

I am grateful to a number of people for their help in providing me with the survey data I discuss in this piece, but I must especially thank Mari Harris of Markinor, Lorraine Glanz and Ian Hirschfeld of the Human Sciences Research Council, David Everatt of the Community Agency for Social Enquiry, and Janine Rauch of the Centre for the Study of Violence and Reconciliation, for their assistance in this effort. Gail Gerhart also supplied me with a range of useful material, as did Kate McLeod of the New York Law School Library. I am also very grateful to Geoff Budlender, Arthur Chaskalson, Matthew Chaskalson, Aninka Claassens, Moray Hathorn, and Bongani Majola for their invaluable assistance in arranging the interviews I had the opportunity to conduct while in South Africa in late 1994. In addition, many people have made helpful comments on drafts of this article or on the ideas I have been exploring in it. There are too many of these people to list them all here, but, in addition to many of the people I have already thanked for other forms of help, I particularly want to thank the participants in a workshop of the University of Cape Town Faculty of Law, the participants in a meeting of the New York Area South Africa Reading Group, several members of the law faculty at the University of the North (in South Africa), as well as Richard Abel, George Bizos, Robert Blecker, John Dugard, Jonathan Klaaren, Gcina Malindi, Gilbert Marcus, Thandabantu Nhlapo, Nancy Rosenbloom, Jeremy Seekings, Michael Sinclair, Nico Steytler, Wim Trengove, Dirk van Zyl Smit, and several anonymous reviewers for Law and Social Inquiry. Lori Lifson provided valuable research assistance. New York Law School provided financial support for this work, and members of NYLS's support staff transcribed the interview tapes.

Finally, I am deeply indebted to the South Africans who generously agreed to be interviewed on tape in connection with this article: Don Nkadimeng, an attorney, law teacher, and senior figure in the Azanian People's Organization; Lucas Kgatitsoe and his colleagues from the Reef committee of the Magopa people; Bethuel Maserumule and Osborne Galeni, both then of the National Union of Metalworkers of South Africa; Nomazizi Mtshotshosa of the National Association of Democratic Lawyers; Mahomed Navsa and Thandi Orleyn, lawyers at the Legal Resources Centre; Mehlolo Tom Rikhoto (Rikhotso), whose case, Oos-Randse Administrasieraad v. Rikhoto, 1983 (3) SA 594 (A), was one of the Legal Resources Centre's first, and most remarkable, legal victories against apartheid; Pansy Tlakula and Tom Lediga of the Black Lawyers Association; and Jotham Zwane, a longtime activist whose agonizing pass law problems were ultimately resolved with the help of the Legal Resources Centre. Though these interviews in no sense constituted a random sample of black opinion, I learned a great deal from the insights and judgments of these black lawyers and clients. 
